\section{Pacific Northwest}

National Laboratory

Operated by Battelle for the

U.S. Department of Energy

\title{
New Technology Demonstration of Microturbine with Heat Recovery at Fort Drum, New York
}

\author{
M. Friedrich \\ P. R. Armstrong \\ D. L. Smith
}

April 2004

Prepared for the

U.S. Department of Energy

Office of Energy Efficiency and Renewable Energy

Federal Energy Management Program

under Contract DE-AC06-76RL01830

and the

U.S. Army Forces Command

under a Related Service Agreement

with the U.S. Department of Energy

under Contract DE-AC06-76RL01830 


\title{
DISCLAIMER
}

This report was prepared as an account of work sponsored by an agency of the United States Government. Neither the United States Government nor any agency thereof, nor Battelle Memorial Institute, nor any of their employees, makes any warranty, express or implied, or assumes any legal liability or responsibility for the accuracy, completeness, or usefulness of any information, apparatus, product, or process disclosed, or represents that its use would not infringe privately owned rights. Reference herein to any specific commercial product, process, or service by trade name, trademark, manufacturer, or otherwise does not necessarily constitute or imply its endorsement, recommendation, or favoring by the United States Government or any agency thereof, or Battelle Memorial Institute. The views and opinions of authors expressed herein do not necessarily state or reflect those of the United States Government or any agency thereof.

\author{
PACIFIC NORTHWEST NATIONAL LABORATORY \\ operated by \\ BATTELLE \\ for the \\ UNITED STATES DEPARTMENT OF ENERGY \\ under Contract DE-AC06-76RL01830
}

Ty 


\title{
New Technology Demonstration of Microturbine with Heat Recovery at Fort Drum, New York
}

\author{
M. Friedrich \\ P. R. Armstrong \\ D. L. Smith
}

April 2004

Prepared for

the U.S. Department of Energy

Office of Energy Efficiency and Renewable Energy

Federal Energy Management Program

under Contract DE-AC06-76RL01830

and the

U.S. Army Forces Command under a Related Service Agreement

with the U.S. Department of Energy

under Contract DE-AC06-76RL01830

Pacific Northwest National Laboratory

Richland, Washington 


\section{Executive Summary}

Escalating energy costs and concerns about electric system reliability, most notably in California and the Northeast, have heightened interest in small-scale power generation as an alternative to dependence on the power grid. Natural gas-fired microturbines can provide both electricity and thermal energy when equipped with a cogeneration package, and they have great overall system efficiencies and low emissions.

In FY 2001, the U.S. Army Forces Command (FORSCOM), with technical assistance from Pacific Northwest National Laboratory, successfully competed for a Federal Energy Management Program (FEMP) Call for Distributed Energy Resources grant to support the demonstration of a small-scale, combined heat and power-configured microturbine system. The demonstration was hosted by the Fort Drum Department of Public Works. Additional support was provided by FORSCOM, the FEMP New Technology Demonstration activity, and the U.S. Army Corps of Engineers-Construction Engineering Research Laboratory.

The purpose of the project was to demonstrate and evaluate a combined heat and powerconfigured microturbine system. The project planned to reduce costs for both electrical energy and electrical demand, reduce environmental emissions, and improve military readiness. The system was designed to supplant a fraction of electrical grid-supplied power and demand while operating in grid-dependent mode. While in grid-independent mode, the system was to be a source of electrical power to operate natural gas-fired boilers in the barracks and handle other minimal loads. The system also provided a portion of the domestic hot water for the barracks and kitchen.

Fort Drum is a 107,000-acre U.S. Army facility located in New York's North Country region a few miles east of Watertown. The Fort consists of over 1,350 buildings totaling more than 7.6 million square feet, and another 7.2 million square feet is family housing facilities.

The Fort Drum microturbine system was installed in the mechanical room of a 500-man barracks and administration complex with full dining facilities. The system included a Capstone $30-\mathrm{kW}$ recuperated microturbine and a micoGen ${ }^{\mathrm{TM}}$ plate/fin-type heat recovery heat exchanger. It used natural gas to produce electricity from the microturbine and used the exhaust gas to heat domestic hot water for the barracks and dining hall.

The electrical output was monitored from startup in May 2002 through July 2003. The heat exchanger output was monitored from September 2002 through July 2003. This report assesses

the efficiency of the microturbine and measures gas emissions, noise level, power quality, microturbine electric power output, and heat exchanger thermal power output over varying operating conditions. 


\section{Results}

One-time tests were performed to determine the sound levels, emissions, and power quality. Measurements of sound indicated $58 \mathrm{dBA}$ at 33 feet, $74 \mathrm{dBA}$ at 18 feet and $85 \mathrm{dBA}$ at 1 foot. Measurements of nitrous oxide (NOx) emissions were $1.5 \mathrm{ppm} \mathrm{NOx} \mathrm{(at} \mathrm{18 \%} \mathrm{O}_{2}$ ) at full load operation and less than $20 \mathrm{ppm}$ at partial load. Carbon monoxide (CO) emissions were also measured, though not given in manufacturer's specifications, and were found to be $10 \mathrm{ppm}$ (at $18 \% \mathrm{O}_{2}$ ) at full load operation and less than $100 \mathrm{ppm}$ at partial load. Data support that the microturbine does not degrade electrical power quality in the building.

Operational performance measurements of electrical capacity at varying air inlet temperature found the microturbine to track specifications very closely, while electrical generating efficiency did not fall as rapidly as the specification does with an increase in temperature and was almost $21 \%$ at $33^{\circ} \mathrm{C}$ (specification is $19.6 \%$ at $33^{\circ} \mathrm{C}$ ). The heat recovery during operation followed the manufacturer's specifications with deviations up to $15 \%$. The overall system efficiency average was $80 \%$ of fuel higher heating value (HHV) when the system was functioning without faults.

The total energy dollars saved at Fort Drum was calculated to be approximately $\$ 2,670$ per year for the first year. The savings would have been higher if the system had been available for operation a larger percentage of the time and if it had been operating without faults. However, the purpose of this demonstration was to validate efficiency performance, not to justify Life Cycle Cost (LCC) at Fort Drum. The savings associated with operating the microturbine include the reduction in utility-supplied electricity and peak demand-plus the value of the recovered waste heat minus the cost of the natural gas consumed by the microturbine.

The demonstration was affected by numerous operations and maintenance problems. Natural gas was delivered to the building at $15 \mathrm{psig}$, and the fuel gas compressor elevated that pressure to $55 \mathrm{psig}$ for use by the microturbine. During the one year of operation, the system required four replacement compressors. Until the reliability of fuel gas compressors is improved, microturbines of this type should be installed only where 55 psig natural gas is available. In addition, there were repeated circuit board failures of the fuel gas compressor controller, the modem, and the heat recovery heat exchanger. 


\section{Acknowledgments}

The authors would like to thank Steve Rowley, energy manager, and Gordon Greene, Chief, JOC/Utility at Fort Drum, for their assistance, energy, and time in making this demonstration a success; John Ashcroft, owner of JW Mechanical, for assisting beyond the scope of his contract; and Steven Parker (PNNL) for his guidance in the conduct of the project. We would also like to thank Steve Jackson (FORSCOM), Ted Collins (FEMP), and Shawn Herrera (FEMP) for their programmatic support of this technology demonstration. 


\section{Acronyms and Abbreviations}

Btu

CERL

CFM

CHP

$\mathrm{CO}$

$\mathrm{CO}_{2}$

$\mathrm{C}_{\mathrm{p}}$

$\mathrm{dB}$

$\mathrm{dBA}$

DDC

DER

DHW

DOE

dP

FEMP

FORSCOM

FS

GPM

$\mathrm{h}$

HHV

HP

inWC

ISO

$\mathrm{kW}$

LHV

LMTD

mBar

MT

$\mathrm{NOx}$

NTU

$\mathrm{O}_{2}$

$\mathrm{P}$

PNNL

ppm

psig

$\rho$

$\operatorname{Rdg}$

RHX

RTD
British thermal units

U.S. Army Construction Engineering Research Laboratory

cubic feet per minute

combined heat and power

carbon monoxide

carbon dioxide

specific heat

decibel

decibel measurement using " $\mathrm{A}$ " weighted scale

direct digital controls

distributed energy resources

domestic hot water

U.S. Department of Energy

differential pressure

Federal Energy Management Program

U.S. Army Forces Command

full scale

gallons per minute

hour

higher heating value

horse power

inches water column

International Organization for Standardization

kilowatt

lower heating value

log-mean temperature difference

millibar

microturbine

nitrous oxides

number of transfer units

oxygen

pressure

Pacific Northwest National Laboratory

parts per million

pounds per square inch gauge

density

reading

recovery heat exchanger

resistance temperature detector 


$\begin{array}{ll}\text { SCF } & \text { standard cubic foot } \\ \text { SOW } & \text { statement of work } \\ \text { Temperature } \\ \text { THD } & \text { total harmonic distortion } \\ \text { U } & \text { overall heat transfer coefficient } \\ \text { UA } & \text { U times the Area (heat exchanger specification) } \\ \text { VAC } & \text { volts alternating current } \\ \text { vf } & \text { volumetric flow }\end{array}$




\section{Contents}

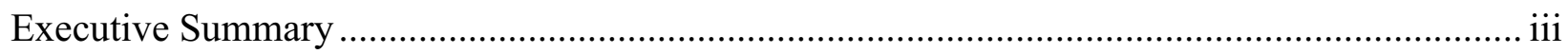

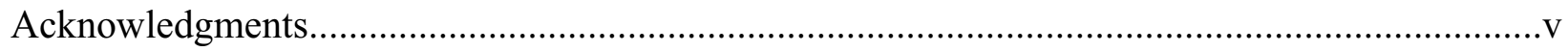

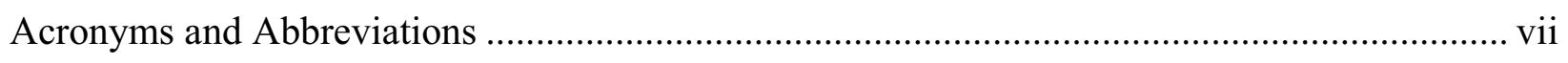

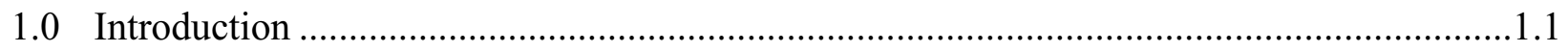

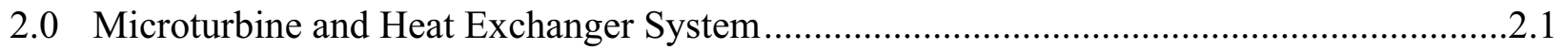

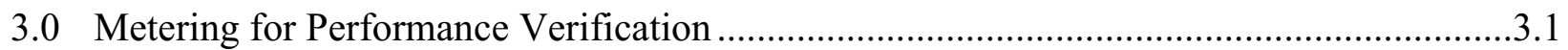

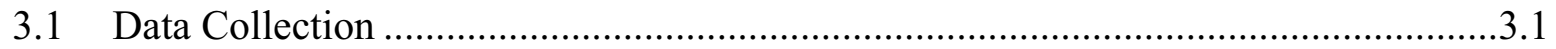

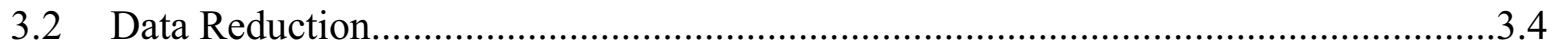

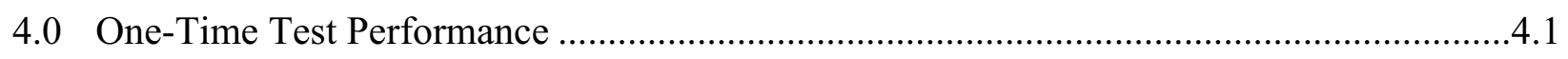

4.1 Average Input, Output, and Inferred Losses .........................................................

4.2 Air Flow Measurement ....................................................................................

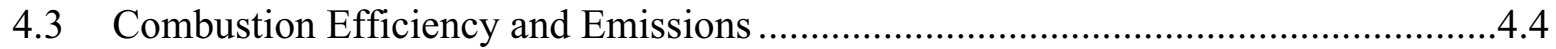

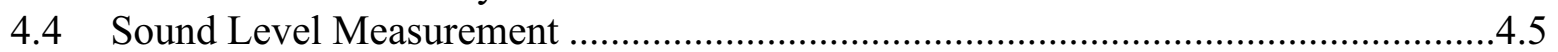

4.5 Electrical Quality Measurement ……………….................................................

4.6 Stand-Alone Test ...................................................................................................... 4.6

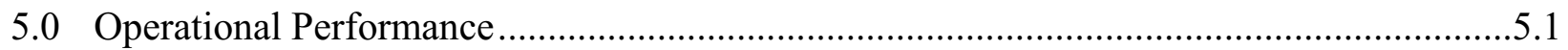

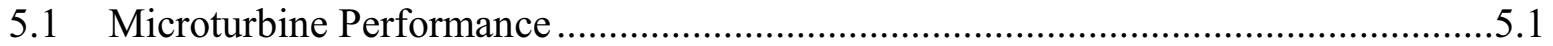

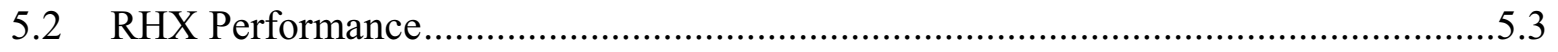

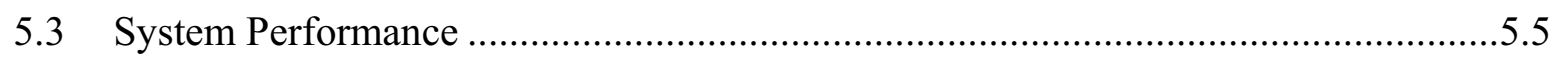

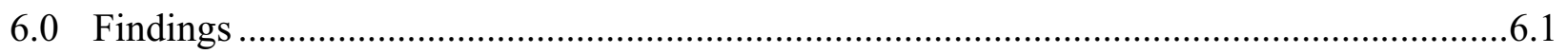

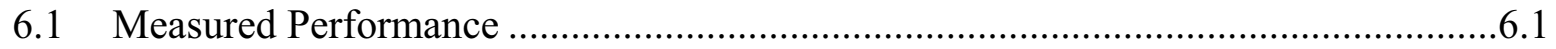

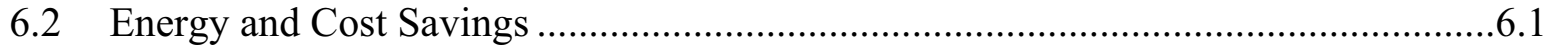

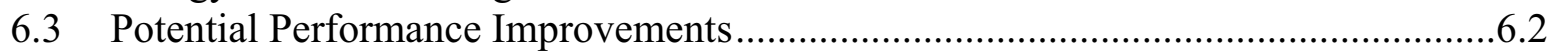

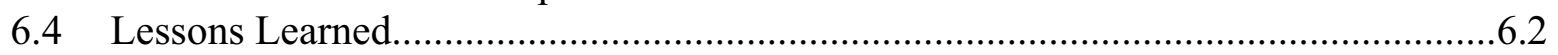

6.5 Fort Drum Energy Manager Feedback ……….......................................................

Appendix A: Design, Installation, and Startup Time Table......................................................

Appendix B: Operational Log...........................................................................................

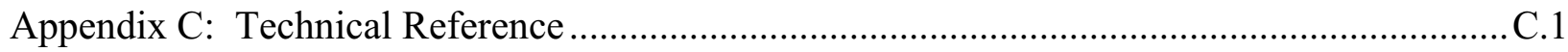

Appendix D: Additional Photographs of Demonstration Setup …………………………….....

Appendix E: Sources and Points of Contact ............................................................................. E.1 


\section{Figures}

2.1 Layout of Microturbine, Heat Exchanger, Tanks, and Circulation Loop .........................2.2

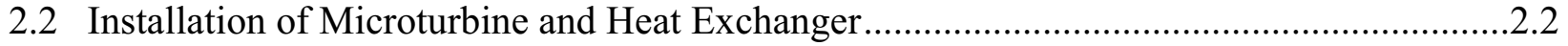

3.1 Data Collection for Performance Verification ..............................................................

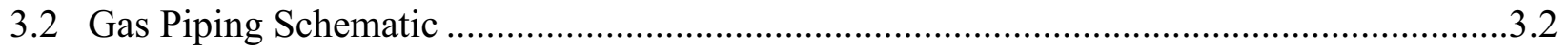

3.3 Volumetric Flow Meter with Gas Temperature and Pressure Sensors at the Outlet and Filter Situated on the Inlet Line ........................................................................

4.1 Comparison of Capstone Specifications of Partial Load Efficiency (\% of HHV) with Measured Data .................................................................................................... 4.2

4.2 Air Intake Measured by a Flow Hood During the One-Time Test ..................................4.3

4.3 Air Flow-Pressure Relation: Data Points and Curve Fit Based on $\mathrm{dP}^{0.5}$ Log-Log Regression...................................................................................... 4.4

5.1 Microturbine Electric Power Output in Relation to Air Inlet Temperature ........................5.2

5.2 Microturbine Efficiency in Relation to Air Inlet Temperature ..........................................5.2

5.3 Fort Drum Microturbine Electric Availability from July 2002 to July 2003 .....................5.3

5.4 Heat Exchanger Water Outlet Temperature Versus Inlet Temperature from September 2002 to January 2003 ........................................................................ 5.4

5.5 Heat Exchanger Heat Recovery Versus Water Inlet Temperature from September 2002 to January 2003 ......................................................................... 5.4

5.6 Heat Exchanger Gas Temperatures and Heat Recovered from September 2002

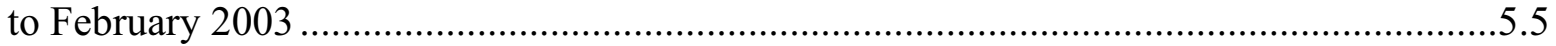

5.7 System Energy Output and Efficiency from September 2002 to March 2003 ...................5.5

\section{Tables}

2.1 Microturbine Specifications at Full Power and ISO ...................................................2.1

2.2 Heat Exchanger Specifications with Capstone 330 at Full Power....................................2.1

3.1 Equipment List for Performance Monitoring …...............................................................3.3

4.1 Average Input, Output, and Inferred Losses for Quasi-Steady Operation.........................4.1

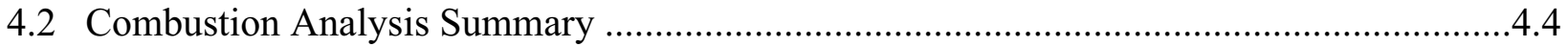

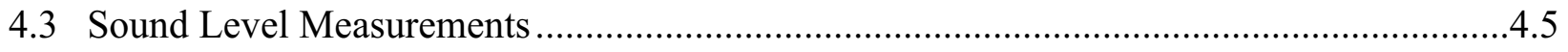




\subsection{Introduction}

Escalating energy costs and concerns about electric system reliability, most notably in California and the Northeast, have heightened interest in small-scale power generation as an alternative to dependence on the power grid. This demonstration project supports the U.S. Army's desire to successfully demonstrate new technologies on their installations and the U.S. Department of Energy (DOE) Federal Energy Management Program (FEMP) New Technology Demonstration activity's mission to demonstrate new energy-saving technologies at federal facilities.

The demonstration was cosponsored by the DOE Federal Energy Management Program and the U.S. Army Forces Command (FORSCOM). Technical assistance was provided by the Pacific Northwest National Laboratory (PNNL) and the U.S. Army Corps of Engineers, Energy Research and Development Center (ERDC), Construction Engineering Research Laboratory (CERL). On site support and coordination was provided by the Department of Public Works' Energy Branch at the host site, Fort Drum, New York.

The purpose of this technology demonstration was to verify the field performance of a microturbine in a combined heat and power configuration. The U.S. Army received an award from the 2001 FEMP call for projects in the amount of $\$ 100,000$ to cover the purchase, design, installation, and maintenance contract, which was used for this technology demonstration. This amount $(\$ 100,000)$ best reflects the overall cost of the project excluding the additional costs associated with the nature of a demonstration project. The microturbine was purchased by CERL through an existing contract mechanism. JW's Mechanical, located in Carthage, New York, was contracted to furnish, install, and maintain the combined heat and power microturbine for the demonstration at Fort Drum.

Microturbines are a new form of distributed generation device manufactured and marketed in the United States. They can provide both electricity and thermal energy (when equipped with a cogeneration package) with good overall system efficiencies. Natural gas-fired microturbines have the potential to deliver multiple benefits, particularly when configured for cogeneration.

The Fort Drum system included a Capstone $30-\mathrm{kW}$ recuperated microturbine that was capable of both grid-parallel and grid-independent operation and a micoGen ${ }^{\mathrm{TM}}$ heat recovery unit. The system was installed in Building P-175, which is a 119,000-square foot, 500-man barracks and administration complex with full (three meals per day) dining facilities. The system used natural gas to produce enough electricity to supplant a fraction of the grid-supplied electricity and used the cogenerated heat for domestic hot water (DHW). A step-down transformer reduced the microturbine generator's 480-volt, three-phase output to 208-volt, threephase to match the barracks electrical distribution system. The microturbine exhaust was ducted

to a micoGen plate/fin-type heat exchanger to preheat domestic hot water for the barracks and dining hall. Based on utility tariffs and costs of both electricity and natural gas, Fort Drum was 
identified as one of the most suitable sites within FORSCOM for this installation. Operational data were collected to demonstrate the performance of the technology for military and other installations. The system's energy performance was monitored by PNNL staff under the FEMP New Technology Demonstration activities. That performance is assessed and reported in this document.

Grid failure initiates a microturbine shutdown and disconnection from the grid. Restart is delayed for approximately five minutes. Upon restart, the microturbine will function in gridindependent mode, with the generated electricity serving only dedicated circuits, including lighting within the mechanical room, natural gas-fired boilers, and a hot-water circulation pump that provides space conditioning for the barracks. Restoration of grid power causes the microturbine to shut down and to restart in grid-parallel mode.

The following are some of the benefits generally attributed to distributed generation and combined heat and power systems:

- Reduced consumption of grid-supplied electrical energy

- Reduced grid-supplied electrical demand

- Reduced costs for both electrical energy and electrical demand

- Reduced environmental emissions

- Increased electrical system reliability

- Improved readiness capability.

This report describes the installed cogeneration equipment and its interface with Building P-175's existing DHW and electrical systems. The instrumentation used for performance verification is also described. Actual performance, based on continuous monitoring and onetime tests, is analyzed and documented. Performance measured under field conditions is compared with rated performance, operational experience is summarized, and recommendations are made for improved commissioning, operation, and efficiency. 


\subsection{Microturbine and Heat Exchanger System}

The equipment procured and used in this demonstration includes a Capstone Turbine Corporation model 330 low-pressure, natural gas-fired microturbine and a Unifin International micoGen model MG1-C1 heat-recovery, heat-exchanger system. The micoGen MG-C1 is specifically designed for integration with the Capstone model 330 microturbine. The manufacturers' equipment specifications are shown Tables 2.1 and 2.2.

Table 2.1. Microturbine Specifications at Full Power and $\mathrm{ISO}^{(\mathrm{a})}$

\begin{tabular}{|l|l|}
\hline \multicolumn{1}{|c|}{ Capstone } & \multicolumn{1}{c|}{ Model 330 } \\
\hline Full-load power output at ISO & $28 \mathrm{~kW}$ electrical \\
\hline Output voltage & $400-480 \mathrm{VAC}$ \\
\hline Electrical frequency & $50 / 60 \mathrm{~Hz}, 3$-phase \\
\hline Efficiency at ISO & $26 \% \mathrm{LHV}(23 \% \mathrm{HHV})$ \\
\hline Natural gas consumption & $122 \mathrm{~kW} \mathrm{HHV}$ \\
\hline Exhaust gas Temperature & $261^{\circ} \mathrm{C}$ \\
\hline Exhaust gas energy & $85 \mathrm{~kW}$ thermal \\
\hline NOx production & $<9 \mathrm{ppm} @ 15 \% \mathrm{O}_{2}$ \\
\hline Sound level & $58 \mathrm{dBA} @ 10 \mathrm{~m}$ \\
\hline Weight & $490 \mathrm{~kg}$ \\
\hline (a) International standard temperature, $15^{\circ} \mathrm{C}$, and pressure, 1 atmosphere. \\
\hline
\end{tabular}

Table 2.2. Heat Exchanger Specifications with Capstone 330 at Full Power

\begin{tabular}{|l|l|}
\hline Unifin micoGen & MG1-C1 \\
\hline Gas side flow rate & $1096 \mathrm{~kg} / \mathrm{hr}$ \\
\hline Water side flow rate & $0.63-3.15 \mathrm{~L} / \mathrm{sec}$ \\
\hline Gas side differential Pressure (max) & $76 \mathrm{~mm} \mathrm{H} \mathrm{H}_{2} \mathrm{O}$ \\
\hline Water side differential Pressure (max) & $11 \mathrm{~m} \mathrm{H} \mathrm{O}_{2} \mathrm{O}$ \\
\hline Maximum water inlet Temperature & $93^{\circ} \mathrm{C}$ \\
\hline Maximum water outlet Temperature & $93^{\circ} \mathrm{C}$ \\
\hline Heat recovery & $41-73 \mathrm{~kW}$ thermal \\
\hline Electric power consumption & $1.1 \mathrm{~kW}$ \\
\hline
\end{tabular}

The equipment was placed inside the existing boiler room, which had ample space for installation. Room revisions included pouring an elevated concrete pad for the microturbine, removing an old insulated water storage tank, purchasing and installing a new 1000-gallon insulated water storage tank, plumbing an existing 1200-gallon storage tank, rewiring the emergency electrical panel, and purchasing and installing a step-down transformer to reduce the microturbine generator's 480-volt, three-phase output to 208-volt, three-phase to match the barracks' electrical distribution system. The system layout is shown schematically in Figure 2.1 and pictured in Figure 2.2. 


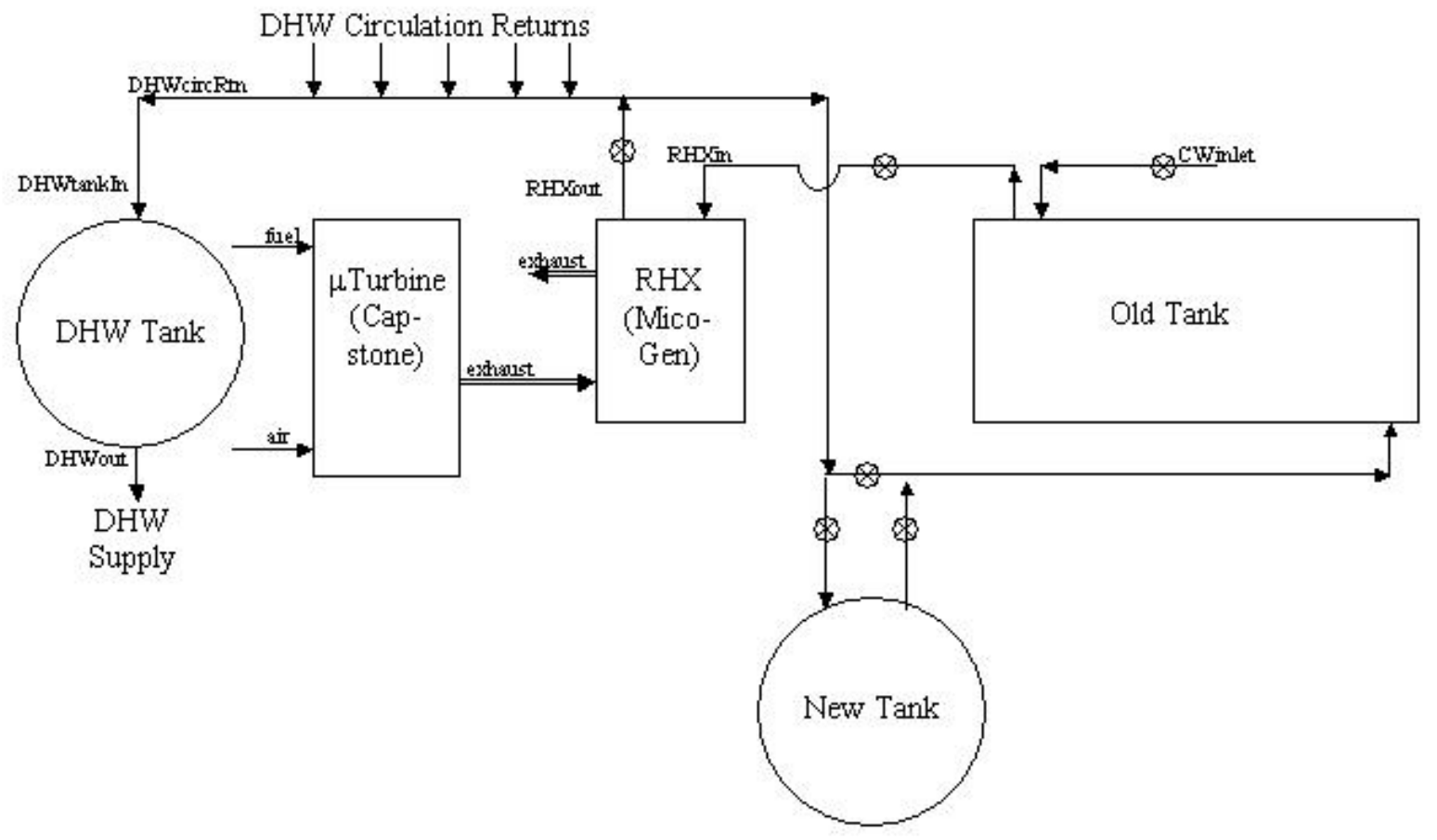

Figure 2.1. Layout of Microturbine, Heat Exchanger, Tanks, and Circulation Loop

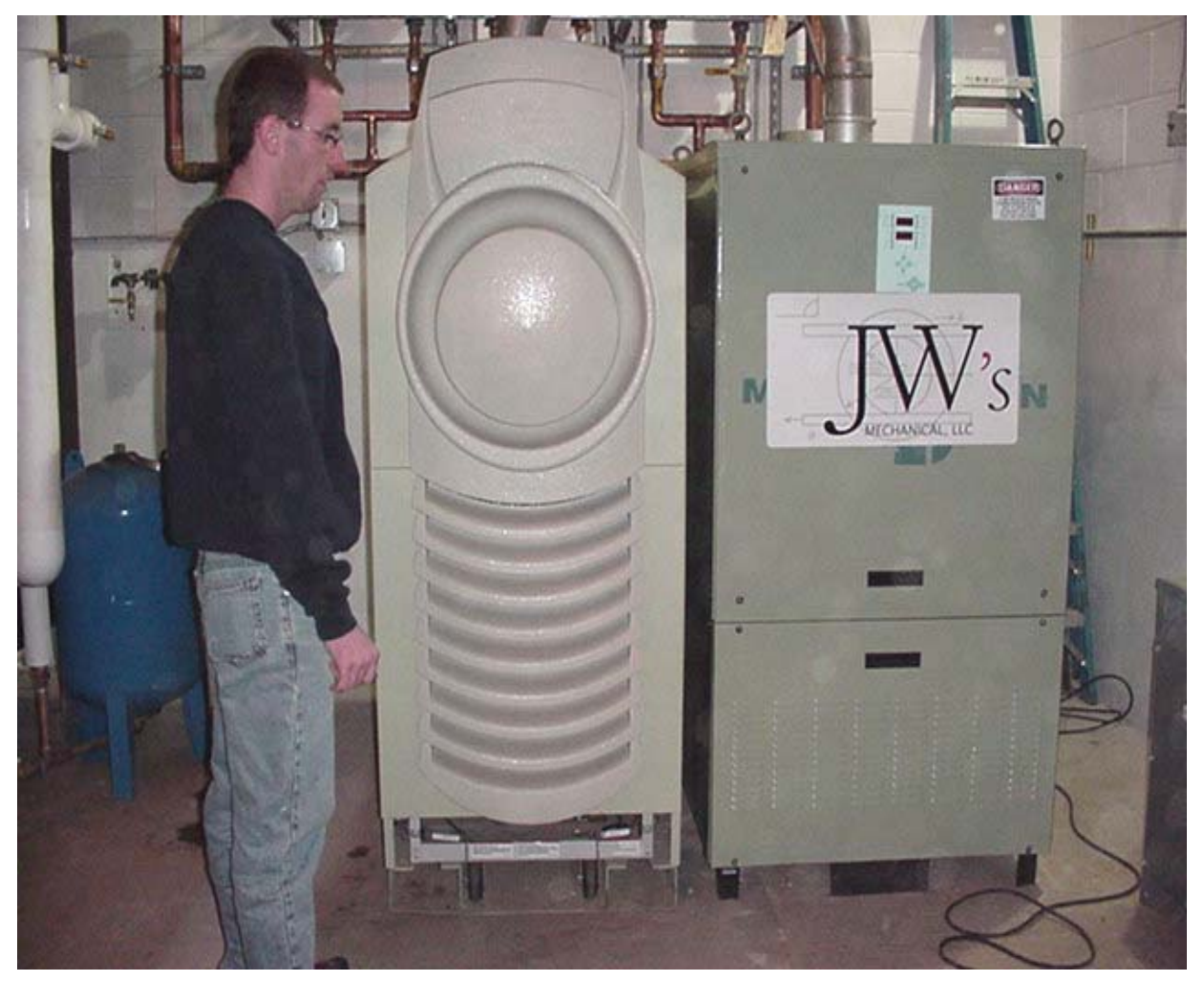

Figure 2.2. Installation of Microturbine and Heat Exchanger 
The system was configured to use the microturbine's electrical output as backup power to boiler room equipment when the electric grid goes down and to supplement the grid when it is active. The existing direct digital control (DDC) system was programmed to start boiler room equipment in case of an electrical grid outage. This equipment includes a 15-HP main circulation pump for building heating, one natural gas-fired boiler for building heat, one DHW boiler, boiler room lights, and a DHW circulation pump.

The heat-recovery, heat-exchanger (RHX) system is designed to heat water to $49^{\circ} \mathrm{C}\left(120^{\circ} \mathrm{F}\right)$ for DHW. Cold makeup water is preheated through a continuous closed-loop system with a storage capacity of 2250 gallons. A 1000-gallon DHW system draws from this loop and further heats the water to $60^{\circ} \mathrm{C}\left(140^{\circ} \mathrm{F}\right)$ for delivery to the barracks and kitchen DHW system.

A turbine is a constant-volume flow device, but its performance depends on mass flow. Therefore, the density of the inlet air, which is a function of its temperature and pressure (altitude), affects the performance of the system. The microturbine used in this demonstration is rated to produce $28 \mathrm{~kW}$ at standard conditions $\left(15^{\circ} \mathrm{C}\right.$, sea level) but is constrained by actual turbine inlet air density and gas inlet pressure. The performance (output capacity) of the microturbine will be less than $28 \mathrm{~kW}$ if the turbine is installed at an elevation above sea level and when the temperature rises above $15^{\circ} \mathrm{C}$. The temperature and elevation deratings are given in Appendix C. The installation at Fort Drum was inside a warm boiler room, so an outside air vent was installed near the turbine to provide cooler air at the microturbine air inlet.

Natural gas is delivered to the building at $15 \mathrm{psig}$. The low-pressure natural gas microturbine model includes a gas booster compressor that degrades the performance of the microturbine by $2 \mathrm{~kW}$ at standard conditions. If 55-psig natural gas could be obtained from the utility, the highpressure natural gas model could be used, and there is an increase not only in electrical output but also in system reliability. Capstone makes models that will operate on gaseous fuels with heat contents ranging from $700 \mathrm{Btu} / \mathrm{SCF}$ to $2516 \mathrm{Btu} / \mathrm{SCF}$ (natural gas, methane, ethane, propane). They also make a low Btu fuel model that will operate on high-pressure gaseous fuels that are between 350 and $700 \mathrm{Btu} / \mathrm{SCF}$ (landfill or digester gas). 


\subsection{Metering for Performance Verification}

\subsection{Data Collection}

Instrumentation was installed and data collected to assess the efficiency of the microturbine (fuel energy in/electric + heat energy out) and to measure gas emissions (CO, NOx), noise level, power quality, microturbine electric power output, and heat exchanger thermal power output over varying operating conditions. Figure 3.1 shows all the measuring points used in the performance verification.

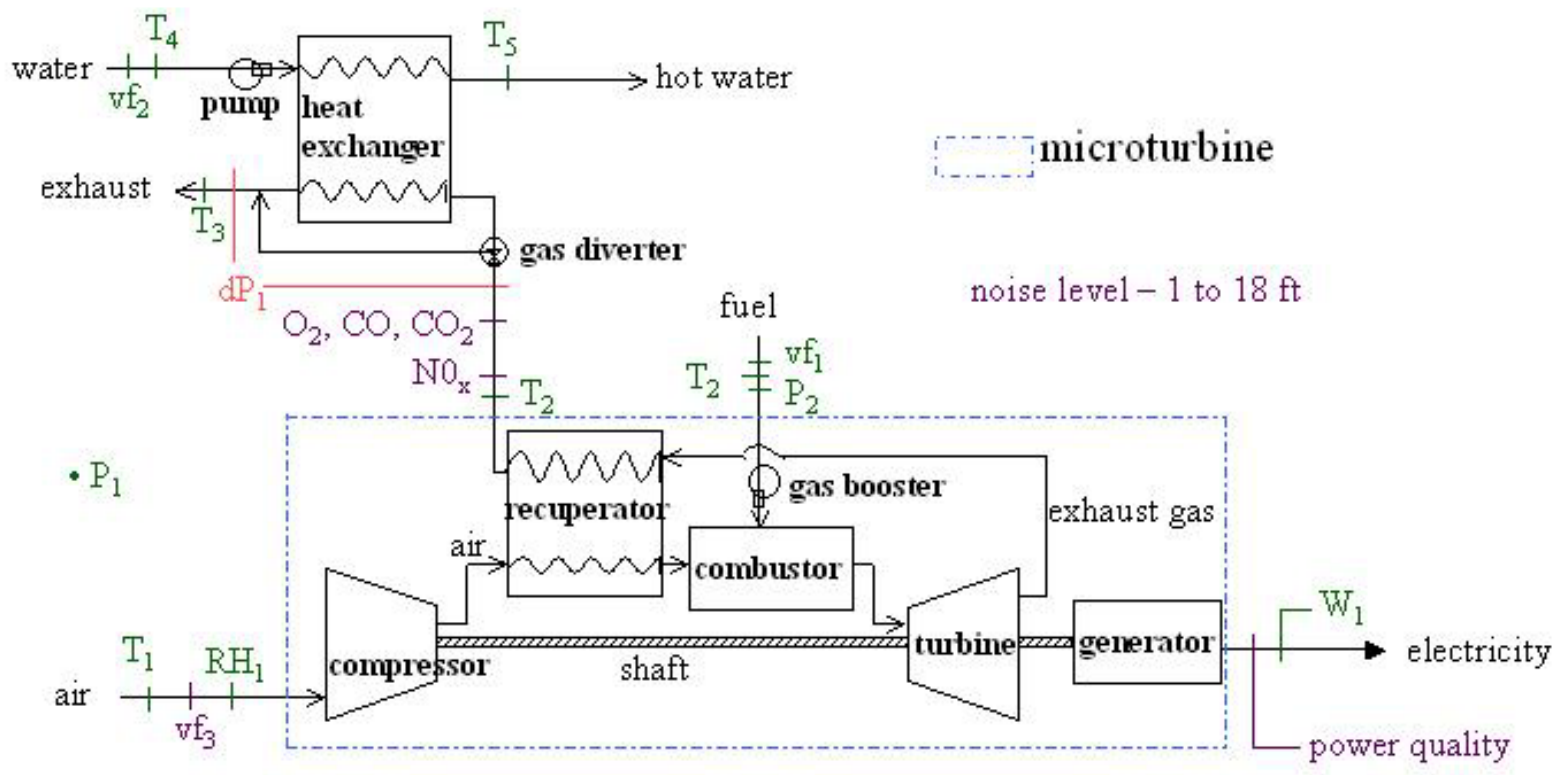

Figure 3.1. Data Collection for Performance Verification

To calculate the efficiency of the microturbine, the fuel energy in and the electric energy and water heating energy out needed to be measured. The volumetric flow rate, pressure, and temperature of the fuel were measured to calculate the mass flow of fuel. The higher heating value (HHV) of the fuel was obtained from the natural gas utility. We were not able to obtain information regarding the composition of the fuel, so the lower heating value (LHV) was estimated to be the higher heating value (HHV) divided by 1.1. (This is the assumption made by Capstone in their specifications.) A watt transducer was used to measure power out of the microturbine. The volumetric flow rate and temperature differential of the water in the recuperative heat exchanger were measured to calculate the heat recovered by the heat exchanger. The specific heat of the water was assumed to be constant in the heat exchanger. 
The gas exit flow rate of the microturbine was to be measured so that a mass and energy balance could be done on the system for error-of-measurement calculations. However, because no mass flow meter exists for combustion exhaust gas, both a combustion analyzer and volumetric flow meter would be needed to determine the mass flow of the exhaust. The cost of those two instruments was beyond the project's budget, however, so that measurement was not made.

The inlet and outlet water temperatures and inlet and outlet gas temperatures of the heat recovery heat exchanger (RHX) were also measured to calculate the log-mean temperature difference (LMTD), effectiveness, number of transfer units (NTU), and overall heat transfer coefficient times the area (UA) of the heat exchanger. A gas differential transducer was installed to measure the gas pressure drop across the heat exchanger. This measurement can be used to measure back pressure on the microturbine and show fouling on the tubes. Technical difficulties were experienced with the transducer; therefore, these data were not collected.

The pressure and temperature of the fuel as well as the temperature, humidity, and pressure of the air were measured to assess their effect on the performance of the microturbine. Figure 3.2 shows the gas piping and measurement layout and Figure 3.3 shows the final gas metering installation.

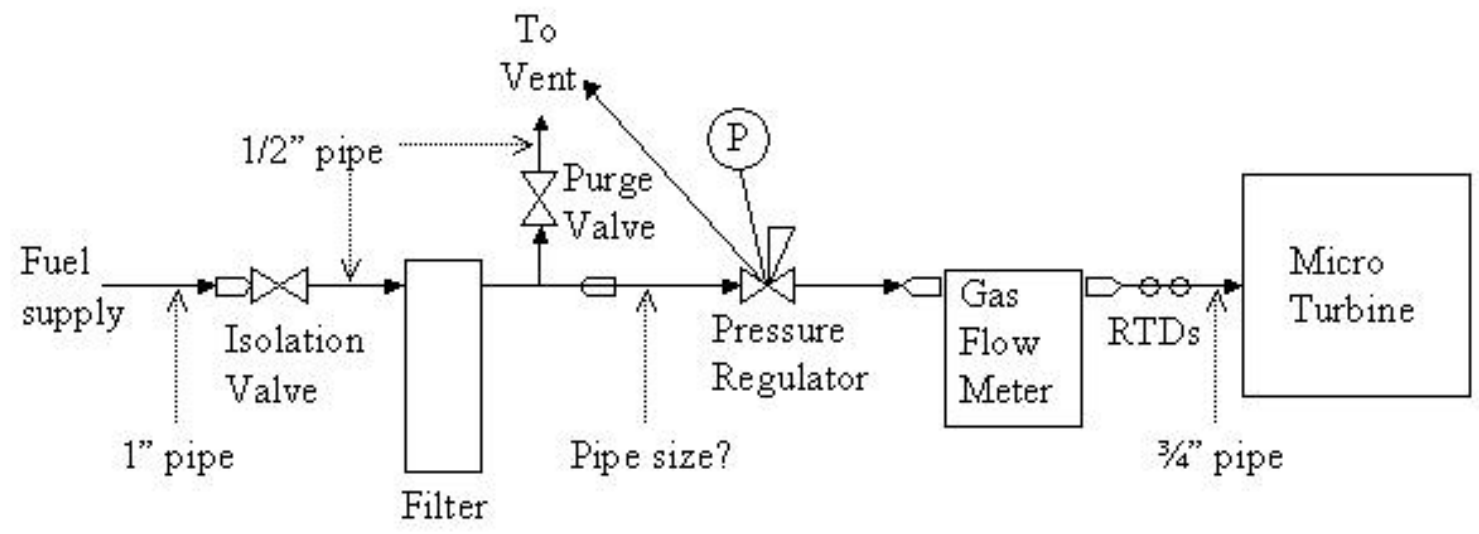

Figure 3.2. Gas Piping Schematic

All of the data collected on the data acquisition system were sampled at a rate of $0.2 \mathrm{~Hz}$ (once every 5 seconds) and at an aggregating and logging rate of once every 5 minutes. The sensors are described by function in Table 3.1. 


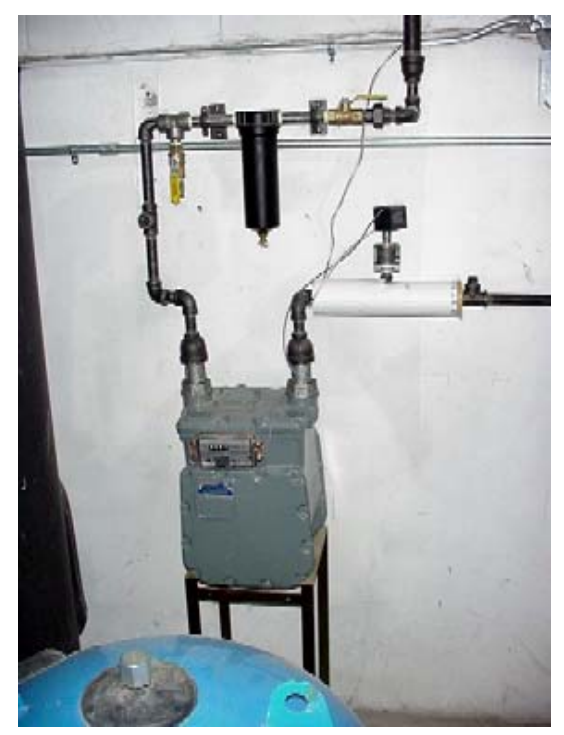

Figure 3.3. Volumetric Flow Meter with Gas Temperature and Pressure Sensors at the Outlet (RightHand Riser) and Filter Situated on the Inlet Line (Left-Hand Riser)

Table 3.1. Equipment List for Performance Monitoring

\begin{tabular}{|c|c|c|c|c|}
\hline Sensor Measurement & Manufacturer & Model & Unit & Accuracy \\
\hline Air temperature at inlet & CS Gordon & Type T, special limits & ${ }^{\circ} \mathrm{C}$ & $0.2^{\circ} \mathrm{C}$ \\
\hline Air relative humidity & Vaisala & HMD-30YB & $\% \mathrm{RH}$ & $1.5 \% \mathrm{RH}$ \\
\hline Air flow meter (dP) & Setra & 264 & inWC & 0.005 inWC \\
\hline Atmospheric pressure & Setra & 270 & mBar & $5.5 \mathrm{mBar}$ \\
\hline Fuel flow meter & American & AL-898 & ACFM & $0.5 \%$ of $\mathrm{rdg}$ \\
\hline Fuel delivery temperature & CS Gordon & Type T, special limits & ${ }^{\circ} \mathrm{C}$ & $0.2^{\circ} \mathrm{C}$ \\
\hline Fuel delivery pressure & Setra & 206 & psig & $0.1 \mathrm{psig}$ \\
\hline Water flow/Btu meter & Niagara/Hersey & $413 / 7437$ & gpm/kBtu & $1 \% \mathrm{FS}$ \\
\hline Water temperature & CS Gordon & Type T, special limits & ${ }^{\circ} \mathrm{C}$ & $0.2^{\circ} \mathrm{C}$ \\
\hline Watt meter & Veris/Hawkeye & H6005 & $\mathrm{kW}$ & $0.2 \mathrm{~kW}$ \\
\hline RHX gas differential pressure & Setra & 264 & inWC & 0.1 inWC \\
\hline Exhaust temperature & Eustis & Type T, special limits & ${ }^{\circ} \mathrm{C}$ & $0.2^{\circ} \mathrm{C}$ \\
\hline Data acquisition system & Campbell Scientific & CRX-10 \& AM25T & - & - \\
\hline Power quality & Fluke & 41 & $\%$ of $1^{\text {st }}$ & $1 \% \mathrm{FS}$ \\
\hline Exhaust gas NOx & Enerac & 3000 & ppm & $1 \mathrm{ppm}$ \\
\hline Exhaust gas CO & Enerac & 3000 & ppm & $5 \%$ of $\mathrm{rdg}$ \\
\hline Exhaust gas $\mathrm{O}_{2}$ & Enerac & 3000 & $\%$ & $1 \%$ \\
\hline \multicolumn{5}{|c|}{$\begin{array}{l}\text { Notes: } \\
\text { ACFM = actual cubic feet per minute } \\
\mathrm{kW}=\text { kilowatts electricity } \\
\mathrm{RH}=\text { relative humidity } \\
\text { inWC = inches water column } \\
\text { rdg = reading } \\
\mathrm{FS}=\text { full-scale }\end{array}$} \\
\hline
\end{tabular}




\subsection{Data Reduction}

A short program was written to aggregate the data over an hour and print them out to a new file. The temperature sensors had intermittent ground loop problems that caused over-range signals (indicated by -6999). The aggregation file ignored the bad data and only aggregated valid temperature readings.

The hourly data were then loaded into a spreadsheet and the following calculations made:

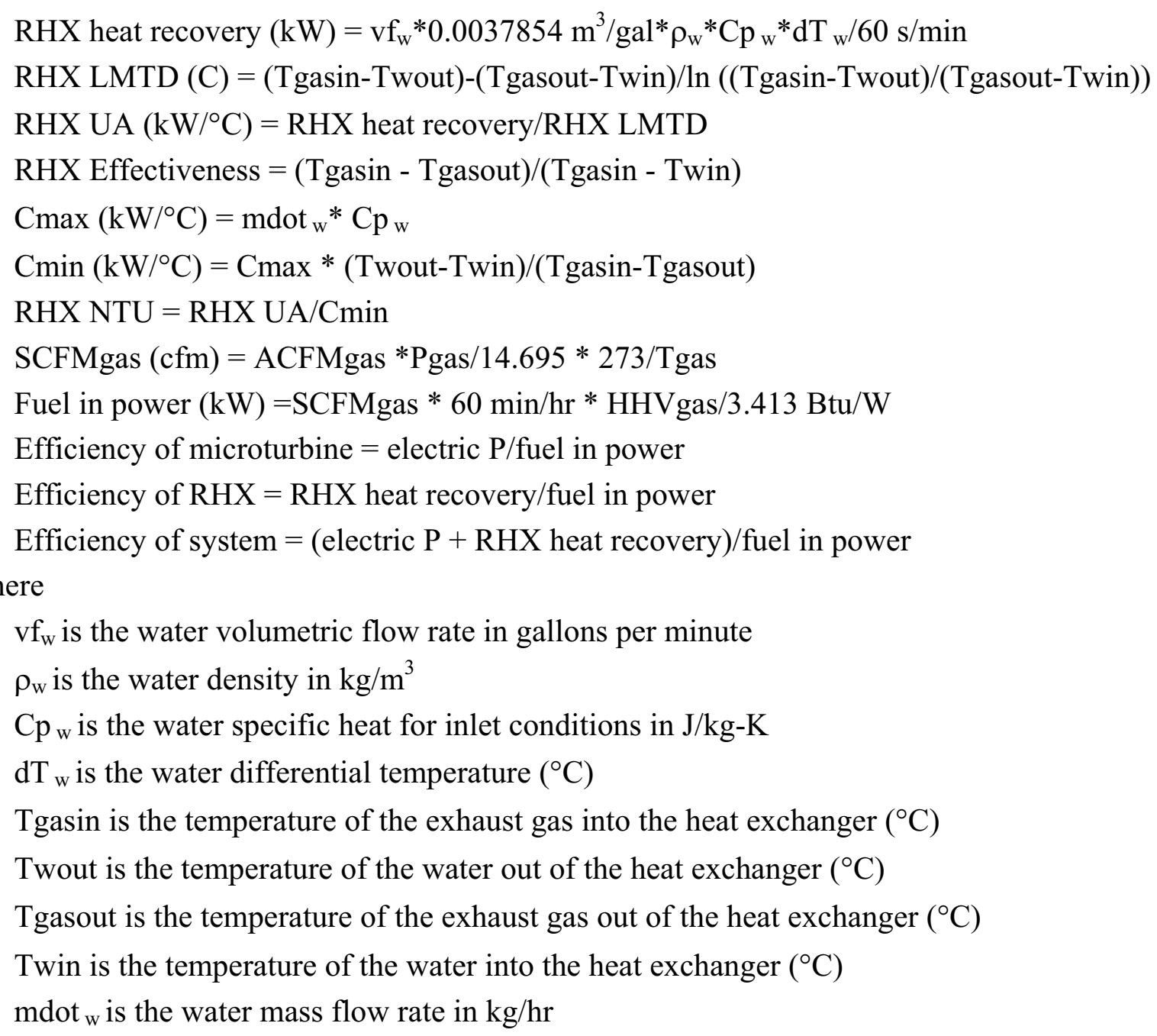

ACFMgas is the actual volumetric flow of natural gas in cubic feet per minute

Pgas is the absolute pressure of the natural gas (psia)

Tgas is the temperature of the natural gas $(\mathrm{K})$

HHVgas is the monthly average higher heating value of the gas given by the utility $\left(\mathrm{Btu} / \mathrm{ft}^{3}\right)$ Electric $\mathrm{P}$ is the electric power out of the microturbine $(\mathrm{kW})$. 


\subsection{One-Time Test Performance}

In the spring of 2002, the turbine was operated manually to obtain performance data at a series of partial load operating points. In addition to the variables measured by the PNNL data acquisition system, several one-time measurements were made to characterize emissions, combustion efficiency, and inlet air flow. The results of these tests are reported in this section.

\subsection{Average Input, Output, and Inferred Losses}

The values measured by the data acquisition system and associated derived values are reported in Table 4.1 for six periods of quasi-steady operation. Electrical efficiency was measured two ways. The first is from the combustion analysis based on measured intake air and exhaust temperatures and excess air percent based on exhaust oxygen $\left(\mathrm{O}_{2}\right)$ content. The second is electrical output divided by the higher heating value of fuel.

The last five rows express the outputs and losses as a percent of the fuel HHV input. The $\mathrm{HHV}$ is assumed to be $1006 \mathrm{Btu} / \mathrm{ft}^{3}$ (utility monthly average). The first four of these numbers come directly from the kBtu values reported earlier in the table. The last row expresses the sum of electrical and heat exchanger output, i.e., the combined thermal and electrical outputs, as a percent of input. This is defined as CHP overall efficiency.

Table 4.1. Average Input, Output, and Inferred Losses for Quasi-Steady Operation

\begin{tabular}{|c|c|c|c|c|c|c|}
\hline \multirow[b]{2}{*}{ Description (units) } & \multicolumn{6}{|c|}{ Percent Full Load } \\
\hline & $100 \%$ & $86 \%$ & $75 \%$ & $56 \%$ & $37 \%$ & $18 \%$ \\
\hline Electric output (kW) & 26.6 & 22.9 & 19.9 & 14.8 & 9.8 & 4.8 \\
\hline \multicolumn{7}{|l|}{ Energy Balance (units) } \\
\hline Fuel input [HHV] (kBtu/hr) & 429 & 377 & 341 & 283 & 218 & 159 \\
\hline Heat recovered [RHX] (kBtu/hr) & 233 & 208 & 185 & 152 & 122 & 49 \\
\hline Electric output (kBtu/hr) & 91 & 78 & 68 & 51 & 33 & 16 \\
\hline Jacket loss [approx.] (kBtu/hr) & 77 & 64 & 64 & 68 & 51 & 77 \\
\hline Exhaust loss [approx] (kBtu/hr) & 28 & 27 & 24 & 12 & 11 & 16 \\
\hline \multicolumn{7}{|l|}{ Efficiency $^{(1)}$} \\
\hline Heat recovered & $54.3 \%$ & $55.1 \%$ & $54.3 \%$ & $53.7 \%$ & $56.0 \%$ & $31.0 \%$ \\
\hline Electric output & $21.2 \%$ & $20.7 \%$ & $19.9 \%$ & $17.9 \%$ & $15.4 \%$ & $10.4 \%$ \\
\hline Jacket loss & $17.9 \%$ & $17.0 \%$ & $18.8 \%$ & $21.4 \%$ & $23.5 \%$ & $48.6 \%$ \\
\hline Exhaust loss & $6.5 \%$ & $7.2 \%$ & $7.0 \%$ & $4.2 \%$ & $5.1 \%$ & $10.1 \%$ \\
\hline Overall CHP efficiency $^{(2)}$ & $75.5 \%$ & $75.9 \%$ & $74.3 \%$ & $71.6 \%$ & $71.4 \%$ & $41.4 \%$ \\
\hline \multicolumn{7}{|c|}{$\begin{array}{l}\text { (1) Efficiency calculations based on fuel higher-heating value. } \\
\text { (2) Overall CHP efficiency determined as: }\end{array}$} \\
\hline
\end{tabular}


A comparison between the Capstone specifications and the test data for partial load efficiency is shown in Figure 4.1. The Capstone data was modified to account for air pressure and temperature derating at the test conditions. As you can see, the microturbine efficiency decreases only $17 \%$ with a $50 \%$ reduction in electrical power generation.

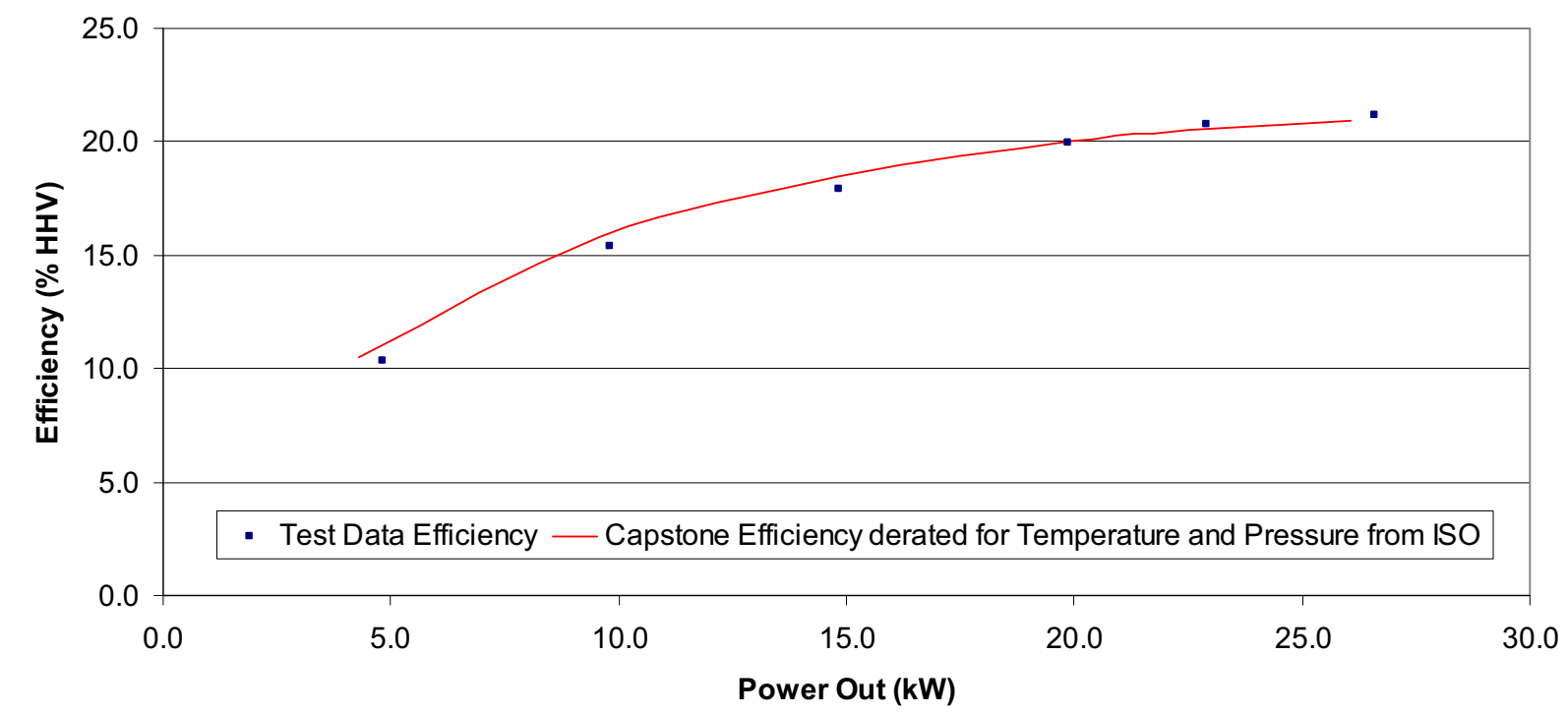

Figure 4.1. Comparison of Capstone Specifications of Partial Load Efficiency ( $\%$ of HHV) with Measured Data

Jacket losses are calculated as follows:

$$
\text { RHX heat recovery }=(\text { Twout }- \text { Twin }) * \rho_{\mathrm{w}}{ }^{*} \mathrm{Cp}_{\mathrm{w}} * \mathrm{vf}_{\mathrm{w}}
$$

where $C p_{\mathrm{w}}$ is water specific heat $(4177 \mathrm{~J} / \mathrm{kg}-\mathrm{K}), \mathrm{vf}_{\mathrm{w}}$ is the water volumetric flow rate, Twout is the temperature of the water out of the heat exchanger, Twin is the temperature of the water into the heat exchanger and $\rho_{\mathrm{w}}$ is the water density.

$$
\mathrm{Q}_{\mathrm{RHXexh}}=\mathrm{Q}_{\mathrm{MTexh}}\left(\mathrm{T}_{\text {gasout }}-\mathrm{T}_{\text {air }}\right) /\left(\mathrm{T}_{\text {gasin }}-\mathrm{T}_{\text {air }}\right)
$$

where $\mathrm{Q}_{\mathrm{MTexh}}$ is the energy in exhaust gas leaving the microturbine and is equal to the fuel HHV minus electrical output (thermal equivalent), $Q_{R H X e x h}$ is the energy in the exhaust gas leaving the RHX, Tgasin is the temperature of the exhaust gas into the heat exchanger and Tgasout is the temperature of the exhaust gas out of the heat exchanger.

$$
\text { Jacket loss }=\text { HHV }-Q_{\text {MTexh }}-Q_{\text {RHXexh }}-\text { RHX heat recovery }
$$




\subsection{Air Flow Measurement}

Inlet air flow rate cannot be measured directly without interfering with turbine operation (e.g., increased pressure drop). However, the existing inlet channel can serve as a flow element if properly calibrated. A one-time calibration has been performed using a standard flow hood. Figure 4.2 shows the flow hood installed on the microturbine. Additional pressure drop from the flow hood means that performance is a little off during the process, but the temporary loss of turbine efficiency affects neither the resulting calibration curve nor its subsequent application.

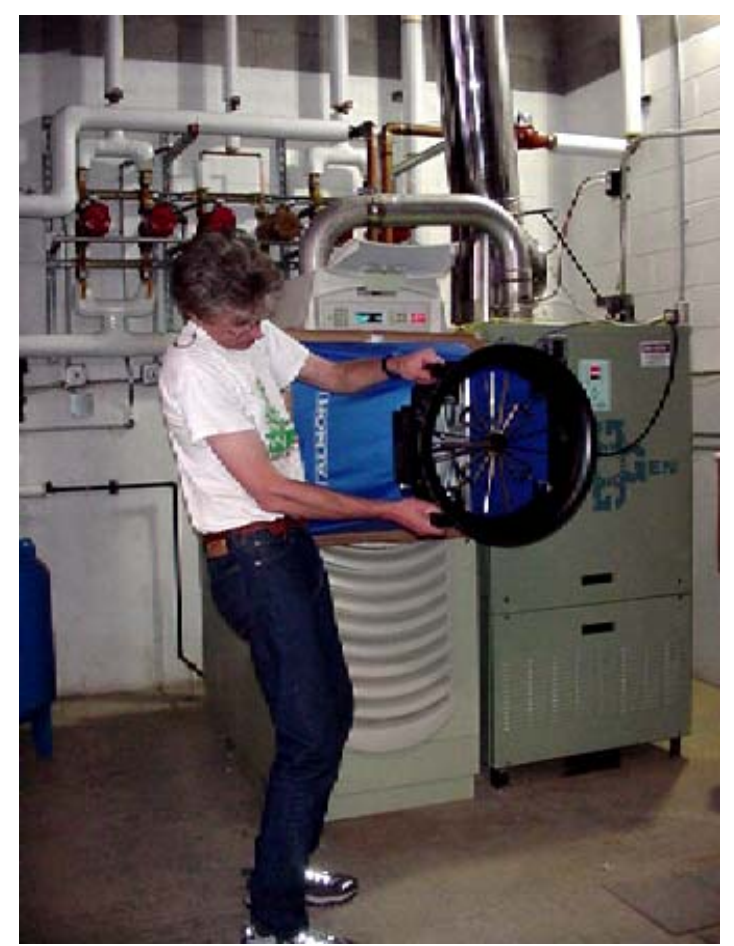

Figure 4.2. Air Intake Measured by a Flow Hood During the One-Time Test

The data are plotted with regression curves in Figure 4.3. Air conditions at the time were 22 to $28^{\circ} \mathrm{C}, 988 \mathrm{mB}$, and 33 to $45 \%$ relative humidity, implying an air density of $1.3 \mathrm{~kg} / \mathrm{m}^{3}$. A log$\log$ regression results in

$$
v f=2035 \mathrm{dP}^{0.5}
$$

with standard error $=4.7 \%$, vf is CFM and $\mathrm{dP}$ is inWC. 


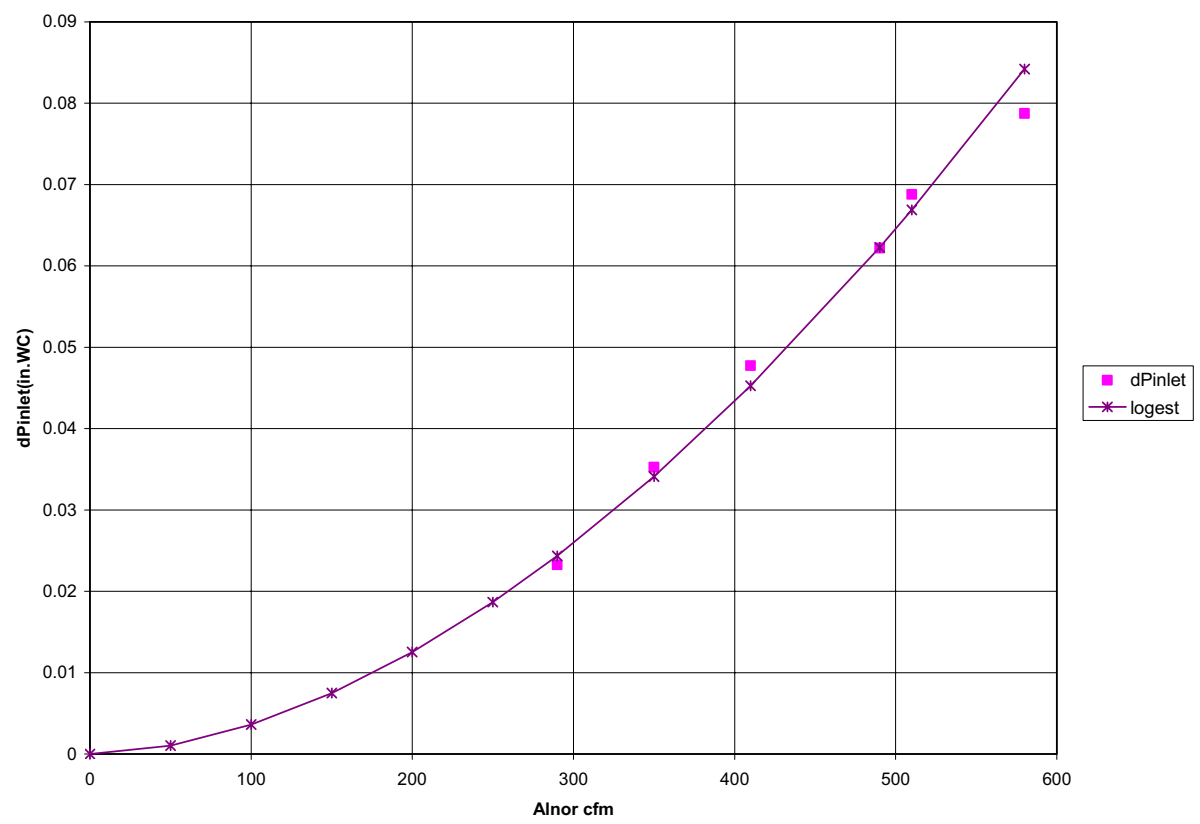

Figure 4.3. Air Flow-Pressure Relation: Data Points and Curve Fit Based on $\mathrm{dP}^{0.5}$ Log-Log Regression

\subsection{Combustion Efficiency and Emissions}

Emissions were measured using a combustion gas analyzer. Calibration gases were shipped to the site, but no adjustments were needed because the analyzer was found to be in good calibration. Exhaust gas constituents were measured at each of six microturbine firing rates, as summarized in Table 4.2. The analyzer also calculates excess air as a percent of the

Table 4.2. Combustion Analysis Summary

\begin{tabular}{|c|c|c|c|c|c|c|}
\hline \multirow[b]{2}{*}{ Description } & \multicolumn{6}{|c|}{ Percent Full Load } \\
\hline & $100 \%$ & $86 \%$ & $75 \%$ & $56 \%$ & $37 \%$ & $18 \%$ \\
\hline Electric output & $26.6 \mathrm{~kW}$ & $22.9 \mathrm{~kW}$ & $19.9 \mathrm{~kW}$ & $14.8 \mathrm{~kW}$ & $9.8 \mathrm{~kW}$ & $4.8 \mathrm{~kW}$ \\
\hline $\begin{array}{l}\text { Efficiency (from Eneract, } \\
\text { based on HHV) }\end{array}$ & $19.2 \%$ & $17.8 \%$ & $17.8 \%$ & $16.9 \%$ & $16.1 \%$ & $11.9 \%$ \\
\hline $\mathrm{O}_{2}$ & $18.2 \%$ & $18.3 \%$ & $18.4 \%$ & $18.4 \%$ & $18.6 \%$ & $18.7 \%$ \\
\hline $\mathrm{CO}$ & $10 \mathrm{ppm}$ & $27 \mathrm{ppm}$ & $74 \mathrm{ppm}$ & $93 \mathrm{ppm}$ & $50 \mathrm{ppm}$ & $99 \mathrm{ppm}$ \\
\hline Combustibles & $0 \%$ & $0.1 \%$ & $0.5 \%$ & $0.1 \%$ & $0.1 \%$ & $0.1 \%$ \\
\hline $\mathrm{CO}_{2}$ & $1.6 \%$ & $1.6 \%$ & $1.5 \%$ & $1.5 \%$ & $1.4 \%$ & $1.3 \%$ \\
\hline $\mathrm{NO}_{\mathrm{x}}$ & $1.5 \mathrm{ppm}$ & $0.5 \mathrm{ppm}$ & $0 \mathrm{ppm}$ & $0 \mathrm{ppm}$ & $20 \mathrm{ppm}$ & $11 \mathrm{ppm}$ \\
\hline Excess air $\left(\mathrm{O}_{2}\right.$ based $)$ & & & $630 \%$ & $660 \%$ & $710 \%$ & $770 \%$ \\
\hline Excess air (flow based) & $600 \%$ & $650 \%$ & $680 \%$ & $720 \%$ & $800 \%$ & $860 \%$ \\
\hline \multicolumn{7}{|l|}{ Time stamp for test } \\
\hline Start & $13: 30$ & $13: 45$ & $13: 51$ & $13: 57$ & $14: 02$ & $14: 07$ \\
\hline End & $13: 44$ & $13: 50$ & $13: 56$ & $14: 01$ & $14: 06$ & $14: 11$ \\
\hline
\end{tabular}


stoichiometric flow rate (flow rate that will theoretically result in $100 \%$ fuel combustion with complete depletion of the oxygen from the combustion air). These excess air numbers are compared with the values calculated on the basis of measured gas and inlet air flow rates converted to standard volume units. The latter estimates of excess air are 9 to $12 \%$ higher than estimates based on $\mathrm{O}_{2}$ concentration. The discrepancies are not surprising. With such large excess air fractions, a tiny error in $\mathrm{O}_{2}$ concentration corresponds to a large error in the calculated volume of excess air.

\subsection{Sound Level Measurement}

Sound level measurements were taken by Industrial Health staff at Fort Drum. The sound level was measured with all other boiler room equipment turned off. Measurements are shown in Table 4.3. Overall noise was not objectionable, although hearing protection should be worn for extended exposure. Because the microturbine was located in the boiler room there were no complaints of noise. If the unit had been installed outside there might have been complaints about the high-pitched whine.

Table 4.3. Sound Level Measurements

\begin{tabular}{||c|c|c|c||}
\hline $\begin{array}{c}\text { Distance from } \\
\text { microturbine } \\
\text { (ft) }\end{array}$ & $\begin{array}{c}\text { Location of } \\
\text { measurement }\end{array}$ & $\begin{array}{c}\text { Frequency of sound } \\
\text { (Hz) }\end{array}$ & $\begin{array}{c}\text { Sound intensity } \\
\text { level } \\
\text { (dBA) }\end{array}$ \\
\hline 1 & front & All & 85 \\
\hline 1 & rear & All & 81 \\
\hline 1 & side & All & 81 \\
\hline 18 & front & All & 74 \\
\hline 18 & front & 12,500 to 20,000 & 57 \\
\hline 18 & front & 2,840 to 5,680 & 74 \\
\hline 18 & front & 177 to 710 & 68 \\
\hline
\end{tabular}

\subsection{Electrical Quality Measurement}

To address power quality concerns regarding the installation of the microturbine, power quality measurements were made on the electrical distribution system in the immediate vicinity of the equipment. The first measurements were taken on May 23-24, 2002, with the microturbine connected and delivering power. The second set of measurements was taken on March 26, 2003, with the microturbine disconnected. The same recording instrument, a Fluke 41 power harmonics analyzer, was used in both instances.

Total harmonic distortion (THD) is a commonly used measure of power quality. THD measures the amount of energy present outside of the primary power frequency, in this case 
$60 \mathrm{~Hz}$. For example, 50\% THD would indicate that the energy present at frequencies other than $60 \mathrm{~Hz}$ is equal to $1 / 2$ the energy present at $60 \mathrm{~Hz}$.

THD measured in the current waveform with the microturbine operating was shown to be on the order of 5\%. In the May 23-24 testing, the project team found that THD actually was higher when measured at points farther from the microturbine. These results indicated that harmonics created by the building's loads were actually worse than those created by the microturbine. Electronic ballasts often produce electrical harmonics and can cause power quality problems.

The hypothesis of the May 23-24 testing was confirmed in follow-up testing conducted March 26 of the next year. THD in the current waveform was shown to be on the order of $10 \%$ on the electrical system without the microturbine connected. Because the majority of the load in the March 26 testing was determined to be lighting, it can be concluded that electronic ballasts within the facility are producing harmonic currents and that the harmonics produced by these devices are significantly greater than those produced by the microturbine. Results of these power-quality field tests are encouraging but not definitive because the existing load is highly nonlinear.

\subsection{Stand-Alone Test}

In addition to the performance verification performed under this demonstration project, the Army requested that a stand-alone or grid-independent test be performed. The purpose of this test was to determine if the combined heat and power system, and the service hot water system it supported, could operate in a grid-independent mode, should the electric utility system go off line. The primary electric end use was a 15 -horsepower motor driving a hot water circulation pump.

During a power outage, the microturbine was expected to provide the energy necessary to operate the hot water circulation pump. The microturbine and the 15-horsepower circulation pump motor were isolated from the main electric utility system, simulating a power outage. The system was then tested in the stand-alone configuration. The testing revealed that during the motor startup, the current draw (in-rush amps) by the motor exceeded the output capacity of the generator resulting in the system tripping off line.

On reflection, this result should have been anticipated regardless of the generator type (microturbine, internal combustion engine, fuel cell, etc.). The starting current (in-rush amps) of an induction electric motor can be several hundred times that of its full-load operating current. Although the in-rush current draw lasts for only a small fraction of a second, it must still be provided by the electric supply system to start the electric motor. A significantly larger generator would be necessary to meet the in-rush power requirements of a 15-horsepower motor. 
Although unsuccessful, an electronic soft start was procured and installed in an attempt to reduce the in-rush current requirements of the 15 -horsepower motor to a level where the $28-\mathrm{kW}$ generator could start the system and remain on line. The generator's overcurrent protection continued to function-tripping the microturbine off. While this does demonstrate that the microturbine's overcurrent protection controls work, it also demonstrates to the users that standalone generators must have the capacity to meet start-up requirements and not just operating requirements. 


\subsection{Operational Performance}

\subsection{Microturbine Performance}

The microturbine electric power output and efficiency were graphed in reference to air inlet temperature and compared with the manufacturer's specifications. The manufacturer's specification data curve was made by using the output values given in Appendix $\mathrm{C}$ and derating for the elevation and pressure at Fort Drum by multiplying by 0.978 (derating value for 14.38 psia atmospheric pressure). The specification data curve was not derated for back pressure because we were unable to measure the backpressure due to a faulty instrument. As can be seen from the graphs in Figures 5.1 and 5.2, the measured data at Fort Drum closely matches the manufacturer's specifications for performance at different air inlet temperatures.

During the demonstration at Fort Drum the atmospheric pressure and natural gas pressure did not vary enough to show the effects of these parameters on performance. The relative humidity was measured and did vary considerably during the demonstration. Analysis of the variation of performance with respect to air humidity on microturbine performance indicated no change in performance with change in humidity.

The electrical output of the microturbine from July 31, 2002 to July 6, 2003 is shown in Figure 5.3. Between February 14 and April 23, 2003, the microturbine was scheduled to be operational during peak electric hours only $(8 \mathrm{am}$ to $10 \mathrm{pm})$. The graph shows output going to zero every night during that period, but the availability is considered $100 \%$ during that time.

For the first year of operation (July 31, 2002 to July 6, 2003) the availability was 74\%. Availability is defined here as the actual operating hours divided by scheduled run hours multiplied by $100 \%$. The reasons for the microturbine being unavailable can be found in Appendix B, Operational Log. 


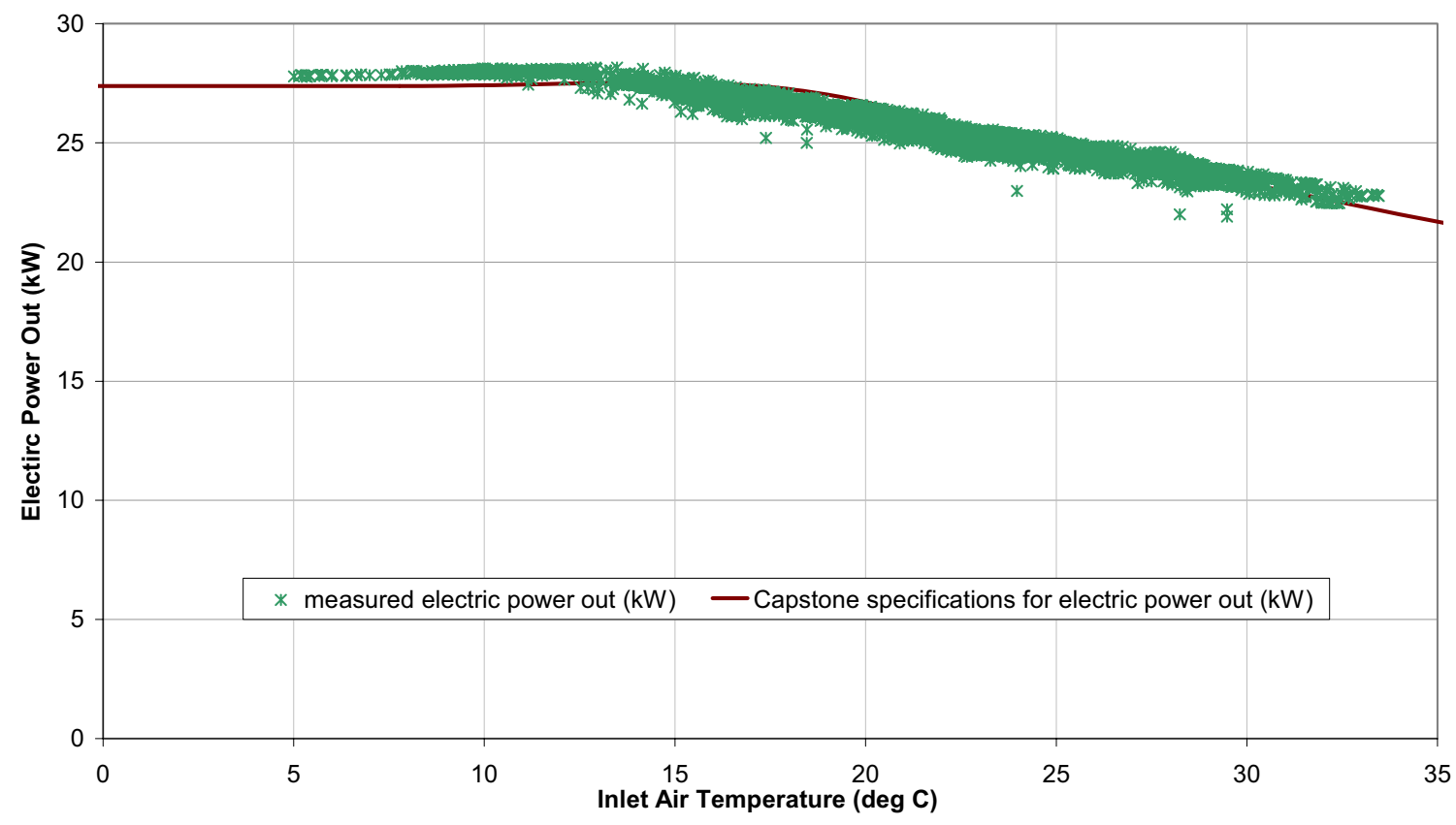

Figure 5.1. Microturbine Electric Power Output in Relation to Air Inlet Temperature

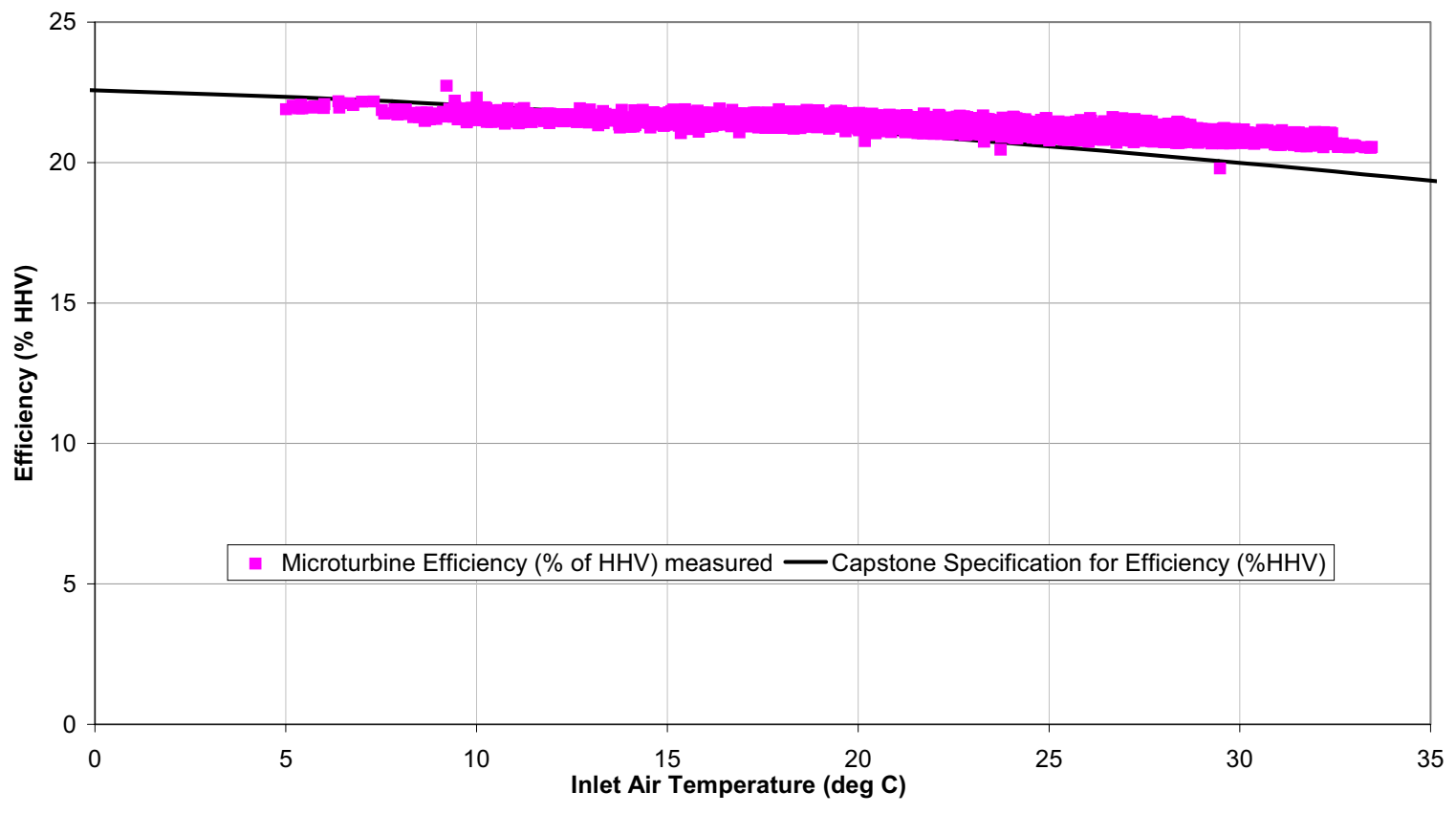

Figure 5.2. Microturbine Efficiency in Relation to Air Inlet Temperature 


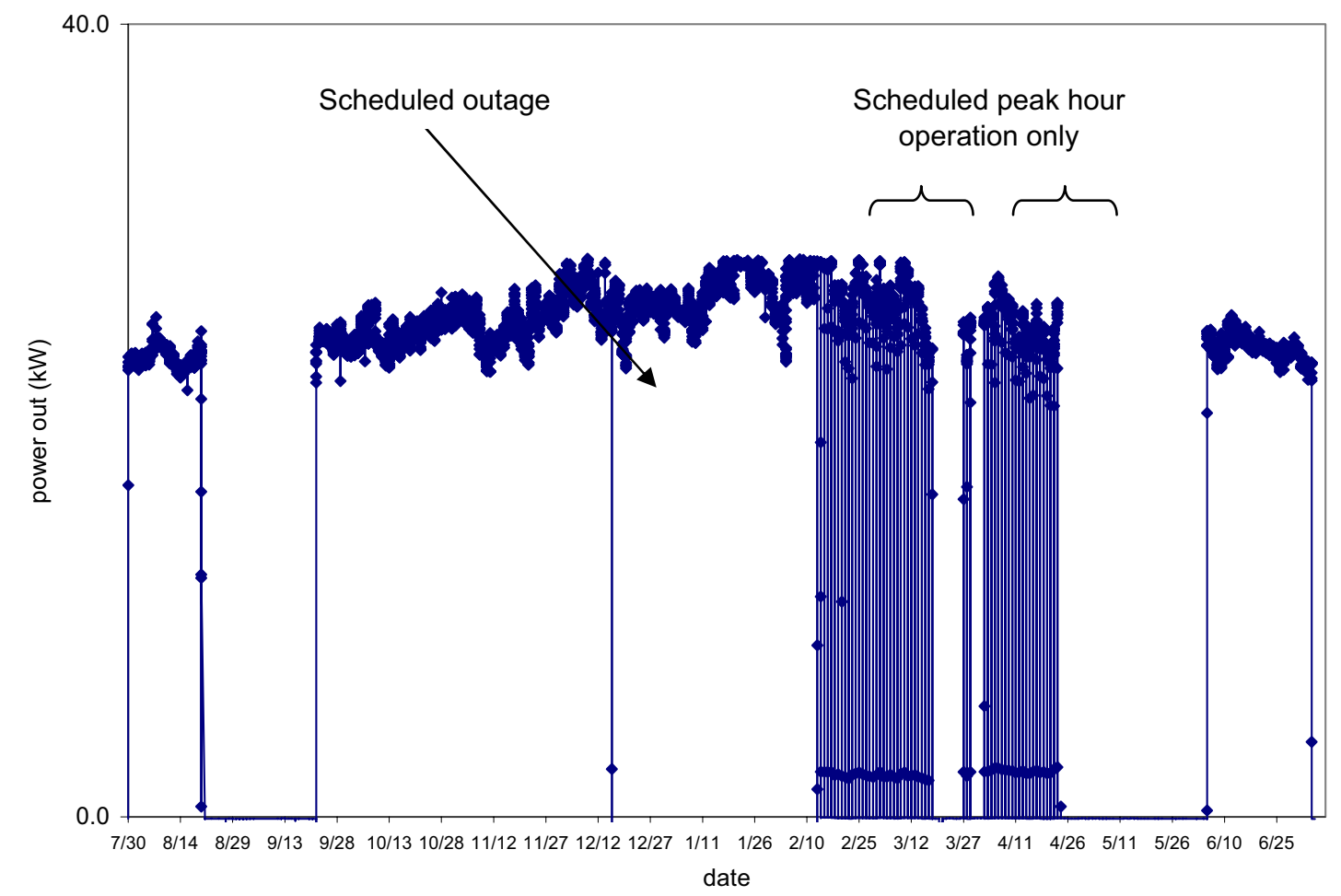

Figure 5.3. Fort Drum Microturbine Electric Availability from July 2002 to July 2003

\subsection{RHX Performance}

The RHX performance was compared with manufacturer's data. Because Unifin has stopped manufacturing the micoGen heat exchangers, the comparisons on the heat exchanger performance are not rigorous. Manufacturer's specifications provide graphs of outlet water temperature and heat recovered versus inlet water temperature. Figures 5.4 and 5.5 compare these parameters with manufacturer's specifications. As can be seen from the graphs, the heat exchanger performed very close to specifications for the water exit temperature, but the heat recovery data seem to indicate that the inlet water temperature had no effect on performance. The data points graphed were taken between September 22, 2002 and January 11, 2003.

As can be seen from Figure 5.6, the heat exchanger had an increase in gas outlet temperature and a drop in heat recovered on January 12, 2003. The gas diverter had stuck partially closed and a fault-detection light did not illuminate on the panel. This reduced the effectiveness of the heat exchanger from 0.89 to 0.70 . The UA of the heat exchanger was 0.66 to $0.69 \mathrm{~kW} /{ }^{\circ} \mathrm{C}$ when the diverter was operating correctly and dropped to 0.39 to $0.32 \mathrm{~kW} /{ }^{\circ} \mathrm{C}$ when it was not. The NTU dropped from 2.3 in early operation to 1.2 with the stuck diverter. 


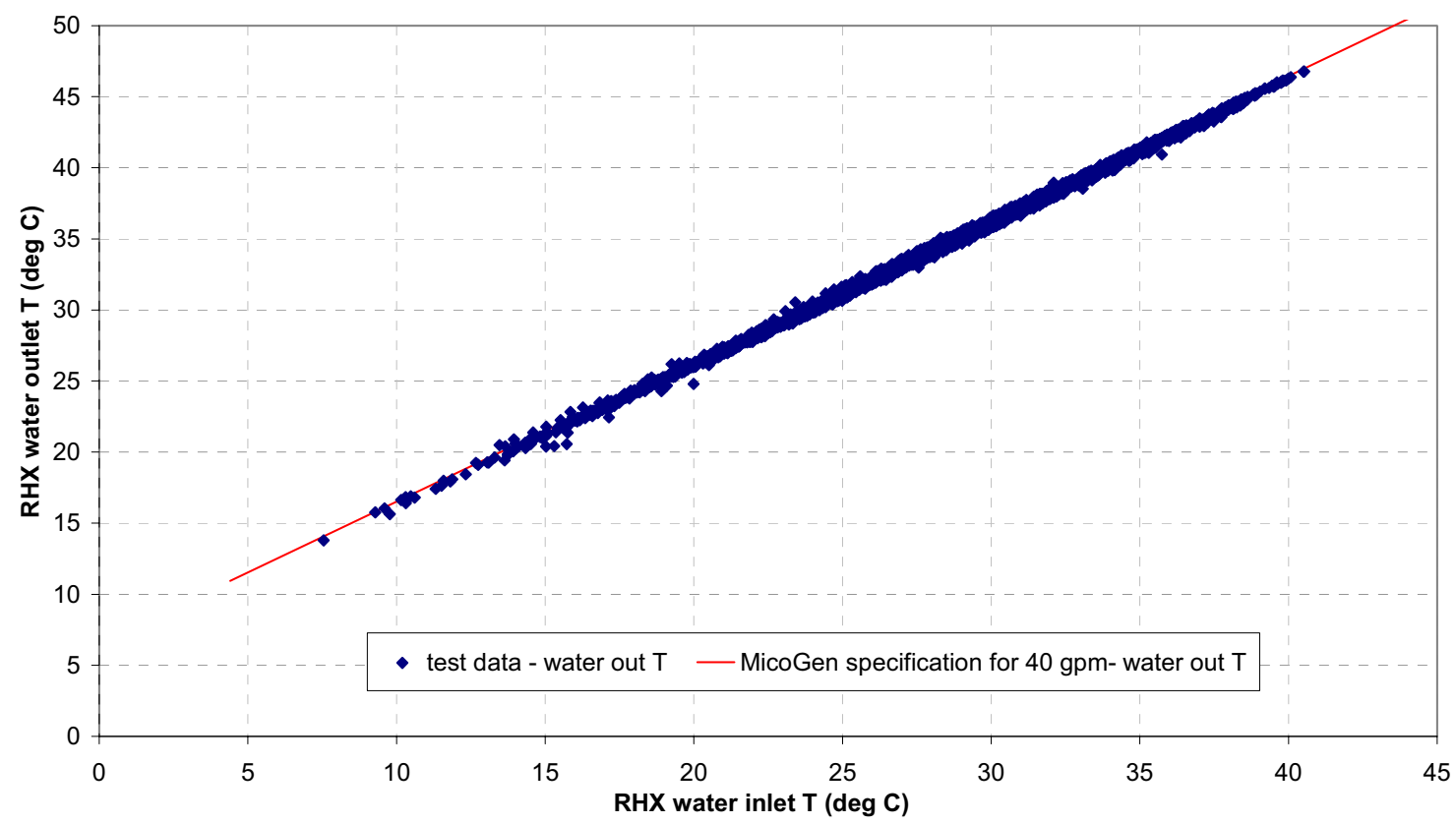

Figure 5.4. Heat Exchanger Water Outlet Temperature Versus Inlet Temperature from September 2002 to January 2003

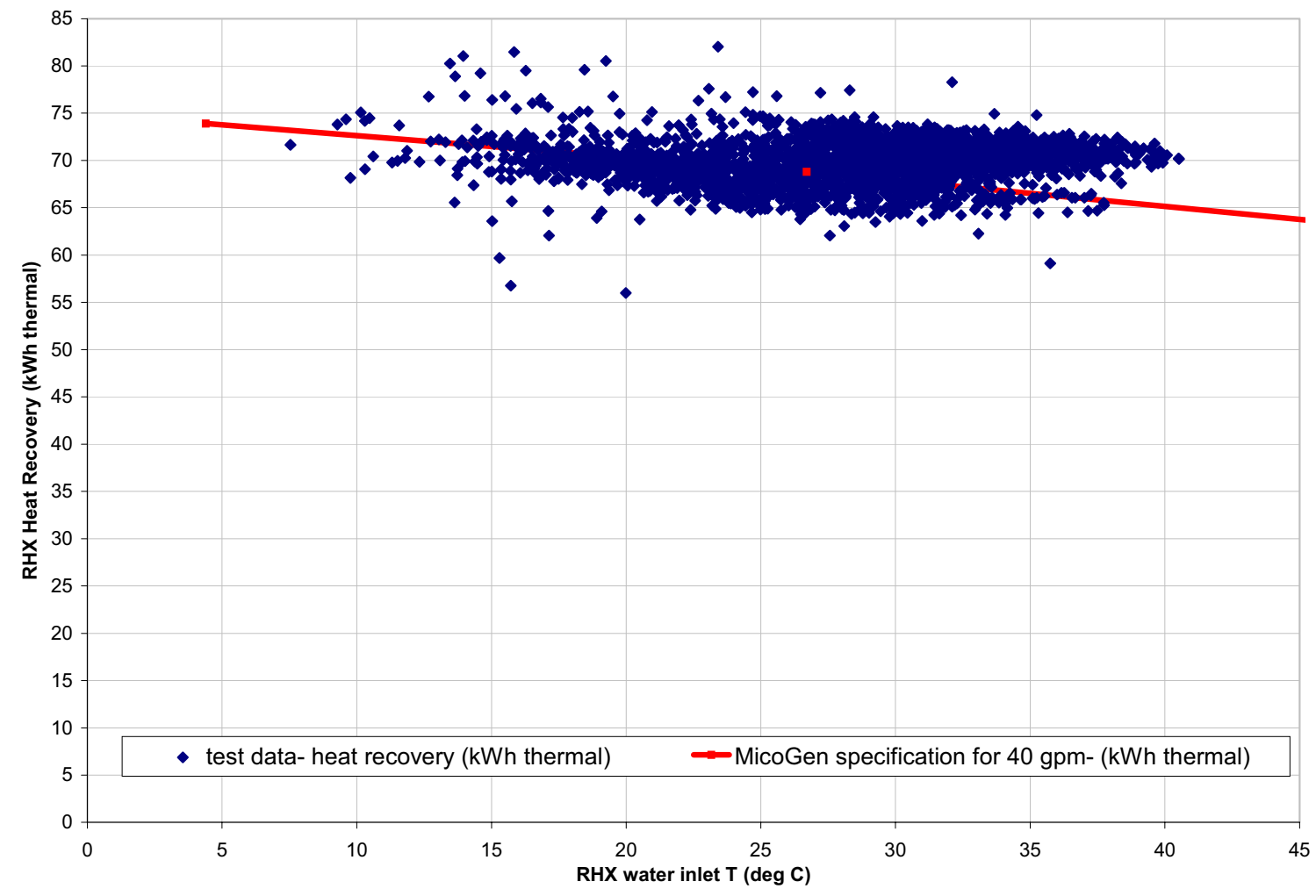

Figure 5.5. Heat Exchanger Heat Recovery Versus Water Inlet Temperature from September 2002 to January 2003 


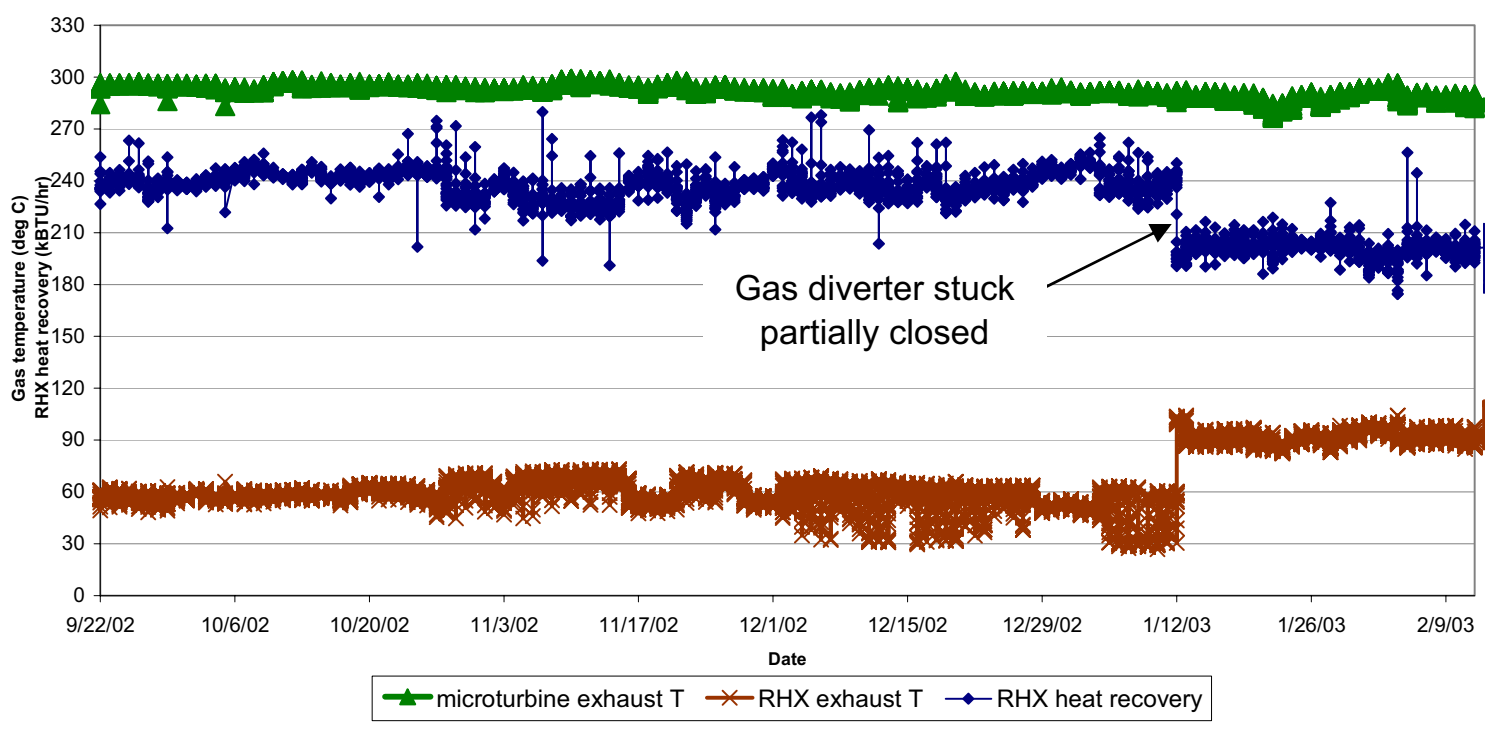

Figure 5.6. Heat Exchanger Gas Temperatures and Heat Recovered from September 2002 to February 2003

\subsection{System Performance}

Figure 5.7 shows the system performance for the first six months of operation. The system efficiency is approximately $80 \%$ until January 12, 2003, when the gas diverter in the heat exchanger stuck partially closed and system efficiency dropped to approximately $67 \%$.

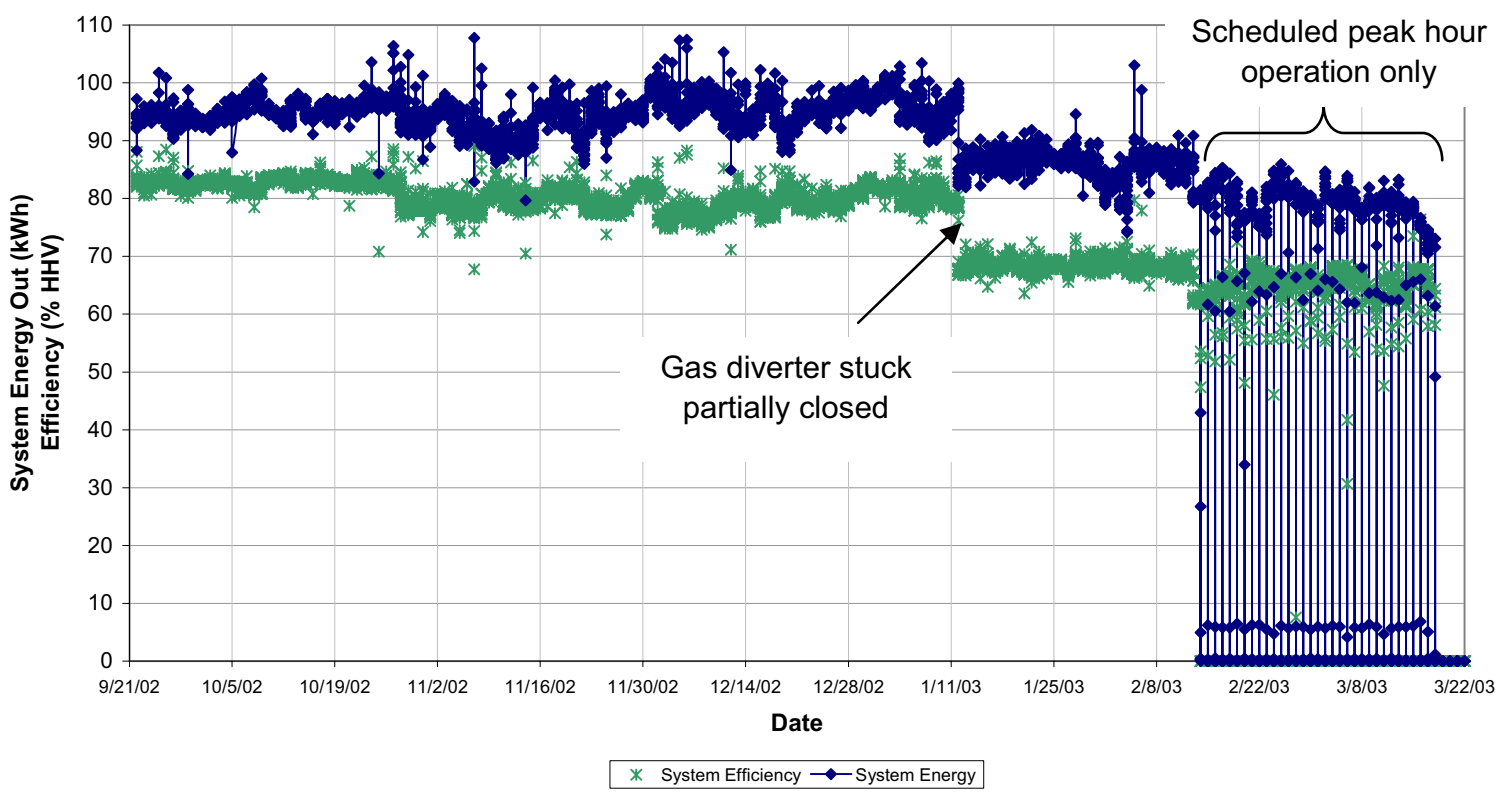

Figure 5.7. System Energy Output and Efficiency from September 2002 to March 2003 


\subsection{Findings}

\subsection{Measured Performance}

One-time tests confirmed the manufacturer's ratings for sound levels and stack emissions. Field measurements are not generally considered to be as accurate as the laboratory measurements upon which the manufacturer's ratings are presumably based.

Total harmonic distortion (THD) in the microturbine output current was measured as $5 \%$ during grid-connected operation. THD of the current at the building service entrance was measured as $10 \%$. This large THD is apparently due to the use of electronic ballasts in almost all of Building P-175's lighting fixtures. We concluded that the microturbine did not degrade power quality significantly in the building.

Electrical capacity was measured over a range of inlet air temperatures and closely tracks the rated sea-level capacity of $27.5 \mathrm{~kW}$ from 5 to $17^{\circ} \mathrm{C}$, diminishing linearly to $22 \mathrm{~kW}$ at $33^{\circ} \mathrm{C}$. However, the measured capacity actually starts to drop sooner, as inlet air temperature approaches $15^{\circ} \mathrm{C}$. Generating efficiency also tracked or exceeded $22 \%$ at $5^{\circ} \mathrm{C}$, diminishing linearly to $19 \%$ at $33^{\circ} \mathrm{C}$. In fact, the measured efficiency did not drop off as rapidly as the rating. The best-fit line gave almost $21 \%$ efficiency at $33^{\circ} \mathrm{C}$.

RHX performance is first-order sensitive to water inlet temperature and flow rate, as indicated in the previous analysis section. The heat exchanger's UA was determined from the measured data to be $0.66-0.69 \mathrm{~kW} /{ }^{\circ} \mathrm{C}$ when the diverter was operating correctly for the first 9 months of operation. This is consistent with the manufacturer's rating.

\subsection{Energy and Cost Savings}

The total saved energy dollars at Fort Drum between August 24, 2002 and July 6, 2003 were calculated. Because the RHX Btu meter was not operational between June and August of 2002 we could not calculate the savings during that time. The calculation was made by adding the cost savings of electricity generated by microturbine, including demand savings, to the cost of natural gas savings for the water heating (assume alternative boilers to have $90 \%$ efficiency) then subtracting the cost of natural gas used to operate the microturbine. The average monthly cost of natural gas at Fort Drum was used, which was between $\$ 0.47$ and $\$ 0.69 /$ therm during this period. The electric cost was assumed to be $\$ 0.0662 / \mathrm{kWh}$ On-Peak ( $8 \mathrm{am}-10 \mathrm{pm}$ Monday -Friday) and $\$ 0.0414 / \mathrm{kWh}$ Off-Peak. Electric demand savings were calculated by taking the minimum electric output from microturbine for the month during Fort Drum peak electric periods and multiplying it by $\$ 5.48 / \mathrm{kW}$-month. Any month the microturbine was not operating during any of the peak hours the demand savings was $\$ 0$. (If we had date and time of demand charge for the 
base we could have checked for operation just at that time.) The total utility savings for August 24, 2002 to July 7, 2003 was \$2310. This is approximately \$2670/year (on an annualized basis) for the first year of operation. ${ }^{\text {(a) }}$ At Fort Drum the water heat recovery was approximately 1.4 billion Btu/yr, or $400,000 \mathrm{kWh}$ thermal/year.

While energy may be saved at the source, energy consumption at the site is increased. This is because of the efficiency of the on-site power generation. DOE is working on a revised energy reporting criteria for federal agencies. The proposed reporting criteria, however, have not yet been approved by the Inter-Agency Task Force. In addition, the proposed reporting criteria have not been integrated into the Army's current energy reporting procedures.

\subsection{Potential Performance Improvements}

Several performance improvements are suggested by the Fort Drum experience with this cogeneration equipment. A small increase in microturbine capacity and improved turbine efficiency can be achieved by providing outside air, via an adequately sized duct, directly to the turbine combustion air inlet. Inlet air cooling could be used to achieve further improvements, albeit at the expense of system complexity and higher first cost.

The RHX diverter damper, which prevents overheating on the water side, could be better controlled to also avoid condensation of the exhaust gas. The gas should be partially diverted when water outlet temperature falls below a specified set point, e.g., $91^{\circ} \mathrm{F}\left(33^{\circ} \mathrm{C}\right)$.

\subsection{Lessons Learned}

Some important lessons were gleaned from the demonstration. The reliability of the gas booster pump must be improved. Until then, gas turbine packages of this type should only be installed where 55 psig of gas is available.

For maximum overall efficiency it is important that sufficient thermal load exist and to install sufficient hot water storage so that the RHX is rarely, if ever, bypassed. In this case there was sufficient thermal load but not sufficient storage. An accurate estimate of hot water demand and its day-to-day variation is important for correctly sizing the system.

The emergency load served in this application was a pump whose in-rush current on startup proved too much for a $28-\mathrm{kW}$ generator. A two-speed motor or delta-wye starter might solve this problem. In any case, it is crucial that the peak start current and duration of such loads be known and matched to the microturbine capability.

(a) Savings would have been greater if gas diverter had not been stuck partially closed for 6 months and if the microturbine had been available during all peak hours. 
According to Unifin and Capstone, the micoGen heat exchanger will no longer be manufactured by Unifin. Capstone now offers a cogeneration package unit with a $60-\mathrm{kW}$ microturbine, but a $30-\mathrm{kW}$ microturbine CHP packaged system is no longer available. If a heat recovery system is to be used with a $30-\mathrm{kW}$ unit, a heat exchanger would need to be procured with the specifications of the micoGen reported earlier in this report.

Based on the operational experience at Fort Drum, there is a clear need for thorough commissioning of the CHP system and associated building controls immediately after installation and before the start of performance monitoring activities.

\subsection{Fort Drum Energy Manager Feedback}

The project was affected by numerous nuisance problems that continually interrupted the test effort. Foremost was the issue of obtaining a reliable gas compressor. Four different compressors have been installed since the microturbine was commissioned. Failures of the circuit boards for the controllers of the gas compressor, modem, and heat exchanger contributed to the problems. The operational log in Appendix B details the problems encountered. During the test effort (May 22, 2002 to July 14, 2003) the microturbine had 69.7\% availability (operational 285 days out of 409). The rest of the time (125 days) the machine was down,

waiting for parts or repairs. Capstone is aware of the field problems that we encountered, and they are addressing these quality control issues. 


\section{Appendix A}

Design, Installation, and Startup Time Table 


\section{Appendix A}

\section{Design, Installation, and Startup Time Table}

\begin{tabular}{|c|c|c|}
\hline Task & Date & Comment \\
\hline Received DOE-FEMP DER grant & April 2001 & \\
\hline $\begin{array}{l}\text { USACE-CERL open market } \\
\text { purchase order }\end{array}$ & June 14, 2001 & $\begin{array}{l}\text { Not to exceed } \$ 100 \mathrm{~K} \text {; selected as } \\
\text { acquisition plan }\end{array}$ \\
\hline $\begin{array}{l}\text { SOW and other information } \\
\text { provided to CERL contracts office }\end{array}$ & August 3, 2001 & $\begin{array}{l}\text { SOW developed with assistance of } \\
\text { CERL }\end{array}$ \\
\hline $\begin{array}{l}\text { Announcement posted in } \\
\text { Commerce Business Daily }\end{array}$ & August 10, 2001 & $\begin{array}{l}100 \% \text { set aside for small business; } \\
\text { firm fixed-price purchase order; } \\
\text { closing date of September } 14,2001\end{array}$ \\
\hline Due date for bids on revised SOW & October 29,2001 & $\begin{array}{l}\begin{array}{l}\text { Original bids exceeded the } \$ 100 \mathrm{~K} \\
\text { threshold }\end{array} \\
\end{array}$ \\
\hline Purchase order issued & November 2001 & \\
\hline Draft system design & December 2001 & $\begin{array}{l}\text { Drawings were less than } 100 \% \\
\text { complete }\end{array}$ \\
\hline $\begin{array}{l}\text { Capstone microturbine unit } \\
\text { delivered to Fort Drum }\end{array}$ & December 2001 & \\
\hline $\begin{array}{l}\text { Unifin micoGen heat exchanger } \\
\text { delivered }\end{array}$ & February 2002 & \\
\hline $\begin{array}{l}\text { Design review meeting with } \\
\text { contractor }\end{array}$ & February 7, 2002 & $\begin{array}{l}\text { Drawings essentially } 100 \% \\
\text { complete; videoconference }\end{array}$ \\
\hline Installation began & February 2002 & \\
\hline $\begin{array}{l}\text { PNNL staff install performance } \\
\text { monitoring and data acquisition } \\
\text { system }\end{array}$ & April 2002 & \\
\hline $\begin{array}{l}\text { Installation of CHP-configured } \\
\text { microturbine system completed } \\
\text { and microturbine commissioned } \\
\text { according to Capstone guidelines. }\end{array}$ & May 2002 & $\begin{array}{l}\text { System operating and data are } \\
\text { being collected; commissioning } \\
\text { was incomplete due to inability to } \\
\text { restart } 15 \text {-hp circulation pump in } \\
\text { stand-alone mode }\end{array}$ \\
\hline $\begin{array}{l}\text { One time testing of the } 15 \text {-hp } \\
\text { circulation pump in the stand alone } \\
\text { mode remains incomplete }\end{array}$ & June 2002 & $\begin{array}{l}\text { Soft-start device does not effect } \\
\text { successful restart; requirement may } \\
\text { be beyond system capability }\end{array}$ \\
\hline
\end{tabular}


Appendix B

\section{Operational Log}




\section{Appendix B \\ Operational Log}

Capstone Microturbine 330 at Fort Drum, New York

Location: Building P-175

System \# 1933

Serial \# 100110

Service Provider: JW's Mechanical, LLC

21 Liberty St.

Carthage, NY 13619

4-26-02, 2 hours

Commissioning Day unit failed to start.

Followed trouble-shooting guide. Called Capstone. Unit had RFC with ceramic bearing, will ship RFC with foil bearing.

5-01-02, 6 hours

Installed new RFC. Unit on line. Commissioning restarted. Unit will not go into stand-alone. Found bad diode in dual-mode controller. Capstone will overnight.

5-04-01, 1.5 hours

Installed diode. Unit will transfer into stand-alone mode but will not maintain load.

5-08-02, 2 hours

Trouble-shooting stand-alone problem

$5-12-02,2.5$ hours

Commissioned microturbine. Worked on emergency equipment commissioning. Troubleshooting stand-alone problem. Unit will run through program on Trane Tracer and start everything except 15 HP pump.

6-01-02, 2 hours

Trouble-shooting micoGen. No response from display. Bad board; Capstone will send new one.

6-04-02

Microturbine repaired and back on line

7-01-02, 3 hours

Microturbine down; trouble-shooting 
7-08-02, 2 hours

Trouble-shooting

7-10-02, 2 hours

Trouble-shooting

7-20-02, 4 hours

Found microturbine down, fault code 6006.

Went through test routine in trouble-shooting manual. Cannot pinpoint problem; will return next week when John Ashcroft can call Capstone.

7-23-02, 3.5 hours.

Leak-checked gas lines between RFC and solenoid block. Tightened loose flare nuts. Plugged bottom of solenoid block, it still leaked. Taped, doped, and retightened, it still leaks. Pulled electrode out and checked end. Found electrode fouled. Dale at Capstone will send solenoid block and electrode overnight. Will upgrade software to unit at time of part installation.

\section{7-25-02, 4 hours}

Installed solenoid block and electrode.

Leak tested.

Found leak at nut leaving SPV.

Leak at male threads entering solenoid block.

Re-used plug for bottom of solenoid block; still did not seal, will purchase new pipe plug.

7-30-02, 3 hours

Installed new plug in solenoid block. Leak checked gas train. All leaks repaired. Unit back on line.

\section{8-26-02, 2 hours}

Trouble-shooting; checked voltages and fuses.

9-12-02, 2 hours

Fault code \#9394 \#9395

Called Capstone, checked RFC. Checked fuses on DPC fuse: F-1 blown- 5 amp fuse; needs to be 8 amp fuse for F-1 and F-2 plus software upgrade to recognize fuse.

Will return with fuses.

\section{9-17-02, 3.5 hours}

Replaced fuses F-1 and F-2 ok. Called Capstone talked with Dale and Igor.

Checked IGB on battery and RFC board.

RFC and RFC controller failed; will ship asap.

Did other trouble-shooting with Capstone. 
9-22-02, 2.5 hours

Installed new RFC and RFC controller.

RFCs \#200-500-60-52, pn\# 511294101R,

RFC controllers \#201377, pn\# 509333303R.

Run hours 1666.33 .

Leak checked gas connections, ok.

Unit on line.

\section{1-6-02 2:30 pm}

Activated DHW supply to kitchen hot water heater.

Nov., Dec., Jan.-Microturbine was on line, running continuously per Steve Parker's request. No indication of major problems. Datalogger data should confirm this; please advise if different.

Shut off kitchen hot water load; this was due to the fact that the heat recovery could not sufficiently pre-heat the makeup water. The AO Smith boilers were experiencing problems and the shops were looking to the microturbine to provide hot water for the building. Installed new board with James Pfeiffer's serviceman. Stand-alone test not successful. 15-hp circ pump will not start.

2-14-03 11 am-3:30 pm

Installed PNNL computer to gather data. Attempted emergency start. 15HP circ pump will not start under microturbine power. Set up microturbine to run.

Daily 8 am - 10 pm

Microturbine down. Attempted two manual restarts with no success. (Rowley)

Microturbine down: couldn't turn gas compressor by hand. Freed up with wrench. Started microturbine.

3-28-03

Microturbine down: attempted successful restart by Rowley.

Microturbine down. Restarted by Ashcroft

4-7-03

OK; still running; water in 53 degrees, water out 61 degrees; 192 starts.

OK; water in 61 degrees, water out 69 degrees F, 199 starts

OK; water in 61 degrees, water out 69 degrees; 199 starts

OK; 2:30 pm, 5 starts; water in 64 degrees, water out 74 degrees; 205 starts 
OK; water in 72, water out 79.

Microturbine down, attempted manual start; won't even try (Rowley).

5-3-03

John installed new modem, modem not working.

5-28-03

Trouble-shooting by John Ashcroft.

USB board bad - codes 7010, 6010, 6012, 11023.

UCB board replaced by John Ashcroft. Turbine started and set to run continuously.

6-7-03 4 PM.

OK; 178 starts; water in@85, out@95 degrees.

6-17-03 noon

OK; gas pressure@12.0 psig; shutoff valve closed half way.

6-30-03 noon

OK; water in 89 , out at 100 degrees F.

7-01-03

OK; water in 98, out 104 degrees.

Turbine down, fuel fault code H6012, suspect gas compressor.

Removed dataloggers (PNNL).

Trouble-shooting by John Ashcroft, RFC controller bad, J5 diode bad. 


\section{Appendix C}

\section{Technical Reference}




\title{
Appendix C
}

\section{Technical Reference}

\author{
Capstone Model C30 Performance ${ }^{(a)}$
}

\section{Introduction}

This document presents performance information for the Capstone Turbine Corporation ${ }^{\circledR}$ Capstone (recuperated) Model C30 MicroTurbine ${ }^{\mathrm{TM}}$ operating on natural gas (B Range) fuel.

The Capstone Model C30 MicroTurbine system is a compact, low emission, power generator providing up to $30 \mathrm{~kW}$ of electrical power. The Model C30 MicroTurbine generates electricity from various fuels with low exhaust emissions. Solid-state power electronics allow Grid Connect or Stand Alone operation.

\section{ISO Full Load Performance}

Performance is listed at full load power and ISO conditions for the Capstone Model C30 MicroTurbine operating on natural gas (B Range) fuel, as defined in the Capstone MicroTurbine Fuel Requirements Technical Reference 410002 . ISO conditions are defined as: $15^{\circ} \mathrm{C}\left(59^{\circ} \mathrm{F}\right), 60 \%$ relative humidity, at sea level altitude. Other items are defined as: HHV: Higher Heating Value, LHV: Lower Heating Value, HPNG: High Pressure Natural Gas, LPNG: Low Pressure Natural Gas, SG: Sour Gas, and UDG: Landfill/Digester Gas. Table 1 presents the (recuperated) Model C30 MicroTurbine performance.

Table 1. Capstone Model C30 MicroTurbine Performance (Grid Connect/Stand-alone)

\begin{tabular}{||l|r|}
\hline \multicolumn{1}{|c|}{ Performance } & \multicolumn{1}{c|}{ Value } \\
\hline Rated Output & $30.0(+0 /-1) \mathrm{kW}$ \\
\hline Thermal Efficiency & $26.0(+/-2) \% \mathrm{LHV}($ Lower Heating Value) \\
\hline Fuel Flow (LHV Based) (See Notes 1 and 2) & $415,000 \mathrm{~kJ} / \mathrm{hr}(394,000 \mathrm{Btu} / \mathrm{hr})$ \\
\hline Fuel Flow (HHV Based) (See Notes 1 and 2) & $457,000 \mathrm{~kJ} / \mathrm{hr}(433,000 \mathrm{Btu} / \mathrm{hr})$ \\
\hline Heat Rate (LHV Based) (See Notes 1 and 2) & $13,800 \mathrm{~kJ} / \mathrm{kWh}(13,100 \mathrm{Btu} / \mathrm{kWh})$ \\
\hline Exhaust Temperature & $275^{\circ} \mathrm{C}\left(530^{\circ} \mathrm{F}\right)$ \\
\hline Exhaust Heat Energy & $327,000 \mathrm{~kJ} / \mathrm{hr}(310,000 \mathrm{Btu} / \mathrm{hr})$ \\
\hline Exhaust Mass Flow & $0.31 \mathrm{~kg} / \mathrm{s}(0.68 \mathrm{lbm} / \mathrm{s})$ \\
\hline
\end{tabular}

Note 1: These parameters are fuel-type dependent.

Note 2: The ratio of higher heating value (HHV) to lower heating value (LHV) is assumed to be 1.1.

\section{Fuel Parameters}

Refer to the Capstone MicroTurbine Fuel Requirements Technical Reference 410002 for detailed information regarding fuel parameters for the Model C30 MicroTurbine.

410004-001 Rev A (August 2002)

(a) Contact Capstone Turbine for current technical specifications. 


\section{Temperature Derating}

Nominal net power output and efficiency versus ambient temperature at sea level for the Model C30 MicroTurbine operating on natural gas (B Range) fuel is presented in Table 2. These values are estimated from nominal performance curves.

Table 2. Nominal Net Power Output and Efficiency versus Ambient Temperature at Sea Level

\begin{tabular}{|c|c|c|c|c|c|c|c|}
\hline $\begin{array}{c}\text { Ambient } \\
\text { Temp } \\
\left({ }^{\circ} \mathbf{F}\right)\end{array}$ & $\begin{array}{c}\text { Net } \\
\text { Power } \\
(\text { kW) }\end{array}$ & $\begin{array}{c}\text { Net } \\
\text { Efficiency } \\
(\%)\end{array}$ & $\begin{array}{c}\text { Exhaust } \\
\text { Temp } \\
\left({ }^{\circ} \mathbf{F}\right)\end{array}$ & $\begin{array}{c}\text { Exhaust Mass } \\
\text { Flow Rate } \\
(\mathrm{lbm} / \mathrm{s})\end{array}$ & $\begin{array}{c}\text { Exhaust } \\
\text { Energy } \\
(\text { Btu/hr) }\end{array}$ & $\begin{array}{c}\text { Fuel Flow } \\
\text { Energy } \\
\text { (LHV) }\end{array}$ & $\begin{array}{c}\text { Heat Rate } \\
\text { (Btu/kWh) } \\
\text { (LHV) }\end{array}$ \\
\hline-4 & 30.0 & 27.9 & 442 & 0.67 & 279,000 & 367,000 & 12,200 \\
\hline-3 & 30.0 & 27.9 & 443 & 0.66 & 279,000 & 367,000 & 12,200 \\
\hline-2 & 30.0 & 27.9 & 445 & 0.66 & 279,000 & 367,000 & 12,200 \\
\hline-1 & 30.0 & 27.9 & 446 & 0.66 & 279,000 & 367,000 & 12,200 \\
\hline 0 & 30.0 & 27.9 & 448 & 0.66 & 279,000 & 367,000 & 12,200 \\
\hline 1 & 30.0 & 27.9 & 450 & 0.66 & 279,000 & 367,000 & 12,200 \\
\hline 2 & 30.0 & 27.9 & 451 & 0.66 & 279,000 & 367,000 & 12,200 \\
\hline 3 & 30.0 & 27.9 & 453 & 0.66 & 279,000 & 367,000 & 12,200 \\
\hline 4 & 30.0 & 27.9 & 454 & 0.66 & 279,000 & 367,000 & 12,200 \\
\hline 5 & 30.0 & 27.9 & 456 & 0.65 & 279,000 & 367,000 & 12,200 \\
\hline 6 & 30.0 & 27.9 & 457 & 0.65 & 279,000 & 367,000 & 12,200 \\
\hline 7 & 30.0 & 27.9 & 459 & 0.65 & 279,000 & 367,000 & 12,200 \\
\hline 8 & 30.0 & 27.9 & 461 & 0.65 & 279,000 & 367,000 & 12,200 \\
\hline 9 & 30.0 & 27.9 & 462 & 0.65 & 279,000 & 367,000 & 12,200 \\
\hline 10 & 30.0 & 27.9 & 464 & 0.65 & 279,000 & 367,000 & 12,200 \\
\hline 11 & 30.0 & 27.9 & 465 & 0.65 & 279,000 & 367,000 & 12,200 \\
\hline 12 & 30.0 & 27.9 & 467 & 0.65 & 279,000 & 367,000 & 12,200 \\
\hline 13 & 30.0 & 27.8 & 468 & 0.65 & 279,000 & 368,000 & 12,300 \\
\hline 14 & 30.0 & 27.8 & 469 & 0.65 & 280,000 & 368,000 & 12,300 \\
\hline 15 & 30.0 & 27.8 & 471 & 0.65 & 280,000 & 369,000 & 12,300 \\
\hline 16 & 30.0 & 27.7 & 472 & 0.65 & 281,000 & 369,000 & 12,300 \\
\hline 17 & 30.0 & 27.7 & 473 & 0.65 & 281,000 & 370,000 & 12,300 \\
\hline 18 & 30.0 & 27.7 & 474 & 0.65 & 282,000 & 370,000 & 12,300 \\
\hline 19 & 30.0 & 27.6 & 476 & 0.65 & 282,000 & 370,000 & 12,300 \\
\hline 20 & 30.0 & 27.6 & 477 & 0.65 & 283,000 & 371,000 & 12,400 \\
\hline 21 & 30.0 & 27.6 & 478 & 0.65 & 283,000 & 371,000 & 12,400 \\
\hline 22 & 30.0 & 27.5 & 479 & 0.65 & 284,000 & 372,000 & 12,400 \\
\hline 23 & 30.0 & 27.5 & 480 & 0.65 & 284,000 & 372,000 & 12,400 \\
\hline 24 & 30.0 & 27.5 & 482 & 0.65 & 285,000 & 373,000 & 12,400 \\
\hline 25 & 30.0 & 27.5 & 483 & 0.65 & 285,000 & 373,000 & 12,400 \\
\hline
\end{tabular}


Table 2. Nominal Net Power Output and Efficiency versus Ambient Temperature at Sea Level

\begin{tabular}{|c|c|c|c|c|c|c|c|}
\hline $\begin{array}{c}\text { Ambient } \\
\text { Temp } \\
\left({ }^{\circ} \mathbf{F}\right)\end{array}$ & $\begin{array}{c}\text { Net } \\
\text { Power } \\
(\mathbf{k W})\end{array}$ & \begin{tabular}{|c|} 
Net \\
Efficiency \\
$(\%)$ \\
\end{tabular} & $\begin{array}{c}\text { Exhaust } \\
\text { Temp } \\
\left({ }^{\circ} \mathbf{F}\right)\end{array}$ & $\begin{array}{c}\text { Exhaust Mass } \\
\begin{array}{c}\text { Flow Rate } \\
(\mathrm{lbm} / \mathrm{s})\end{array} \\
\end{array}$ & $\begin{array}{c}\text { Exhaust } \\
\text { Energy } \\
(\text { Btu/hr) }\end{array}$ & $\begin{array}{c}\text { Fuel Flow } \\
\text { Energy } \\
\text { (LHV) } \\
\end{array}$ & $\begin{array}{c}\text { Heat Rate } \\
\text { (Btu/kWh) } \\
(\text { LHV) }\end{array}$ \\
\hline 26 & 30.0 & 27.4 & 484 & 0.65 & 286,000 & 373,000 & 12,400 \\
\hline 27 & 30.0 & 27.4 & 485 & 0.66 & 286,000 & 374,000 & 12,500 \\
\hline 28 & 30.0 & 27.4 & 487 & 0.66 & 287,000 & 374,000 & 12,500 \\
\hline 29 & 30.0 & 27.3 & 488 & 0.66 & 287,000 & 375,000 & 12,500 \\
\hline 30 & 30.0 & 27.3 & 489 & 0.66 & 288,000 & 375,000 & 12,500 \\
\hline 31 & 30.0 & 27.3 & 490 & 0.66 & 288,000 & 376,000 & 12,500 \\
\hline 32 & 30.0 & 27.2 & 492 & 0.66 & 289,000 & 376,000 & 12,500 \\
\hline 33 & 30.0 & 27.2 & 493 & 0.66 & 289,000 & 377,000 & 12,600 \\
\hline 34 & 30.0 & 27.2 & 494 & 0.66 & 290,000 & 377,000 & 12,600 \\
\hline 35 & 30.0 & 27.1 & 496 & 0.66 & 291,000 & 377,000 & 12,600 \\
\hline 36 & 30.0 & 27.1 & 497 & 0.66 & 291,000 & 378,000 & 12,600 \\
\hline 37 & 30.0 & 27.1 & 498 & 0.66 & 292,000 & 378,000 & 12,600 \\
\hline 38 & 30.0 & 27.0 & 499 & 0.66 & 292,000 & 379,000 & 12,600 \\
\hline 39 & 30.0 & 27.0 & 500 & 0.66 & 293,000 & 379,000 & 12,600 \\
\hline 40 & 30.0 & 27.0 & 502 & 0.66 & 293,000 & 380,000 & 12,700 \\
\hline 41 & 30.0 & 26.9 & 503 & 0.66 & 294,000 & 380,000 & 12,700 \\
\hline 42 & 30.0 & 26.9 & 504 & 0.67 & 295,000 & 381,000 & 12,700 \\
\hline 43 & 30.0 & 26.8 & 506 & 0.67 & 295,000 & 382,000 & 12,700 \\
\hline 44 & 30.0 & 26.8 & 507 & 0.67 & 296,000 & 382,000 & 12,700 \\
\hline 45 & 30.0 & 26.8 & 508 & 0.67 & 297,000 & 383,000 & 12,800 \\
\hline 46 & 30.0 & 267 & 510 & 0.67 & 298,000 & 383,000 & 12,800 \\
\hline 47 & 30.0 & 26.7 & 511 & 0.67 & 298,000 & 384,000 & 12,800 \\
\hline 48 & 30.0 & 26.6 & 512 & 0.67 & 299,000 & 385,000 & 12,800 \\
\hline 49 & 30.0 & 26.6 & 514 & 0.67 & 300,000 & 385,000 & 12,800 \\
\hline 50 & 30.0 & 26.5 & 515 & 0.67 & 301,000 & 386,000 & 12,900 \\
\hline 51 & 30.0 & 26.4 & 517 & 0.67 & 302,000 & 387,000 & 12,900 \\
\hline 52 & 30.0 & 26.4 & 518 & 0.68 & 303,000 & 388,000 & 12,900 \\
\hline 53 & 30.0 & 26.3 & 520 & 0.68 & 304,000 & 389,000 & 13,000 \\
\hline 54 & 30.0 & 26.3 & 521 & 0.68 & 305,000 & 390,000 & 13,000 \\
\hline 55 & 30.0 & 26.2 & 523 & 0.68 & 306,000 & 391,000 & 13,000 \\
\hline 56 & 30.0 & 26.2 & 524 & 0.68 & 307,000 & 391,000 & 13,000 \\
\hline 57 & 30.0 & 26.1 & 526 & 0.68 & 308,000 & 392,000 & 13,100 \\
\hline 58 & 30.0 & 26.1 & 527 & 0.68 & 309,000 & 393,000 & 13,100 \\
\hline 59 & 30.0 & 26.0 & 529 & 0.68 & 310,000 & 394,000 & 13,100 \\
\hline 60 & 30.0 & 25.9 & 530 & 0.68 & 311,000 & 395,000 & 13,200 \\
\hline
\end{tabular}


Table 2. Nominal Net Power Output and Efficiency versus Ambient Temperature at Sea Level

\begin{tabular}{|c|c|c|c|c|c|c|c|}
\hline $\begin{array}{c}\text { Ambient } \\
\text { Temp } \\
\left({ }^{\circ} \mathbf{F}\right)\end{array}$ & $\begin{array}{c}\text { Net } \\
\text { Power } \\
(\mathbf{k W})\end{array}$ & $\begin{array}{c}\text { Net } \\
\text { Efficiency } \\
(\%)\end{array}$ & $\begin{array}{c}\text { Exhaust } \\
\text { Temp } \\
\left({ }^{\circ} \mathbf{F}\right)\end{array}$ & $\begin{array}{c}\text { Exhaust Mass } \\
\text { Flow Rate } \\
(\mathrm{lbm} / \mathrm{s})\end{array}$ & $\begin{array}{c}\text { Exhaust } \\
\text { Energy } \\
\text { (Btu/hr) }\end{array}$ & $\begin{array}{c}\text { Fuel Flow } \\
\text { Energy } \\
(\text { LHV) }\end{array}$ & $\begin{array}{c}\text { Heat Rate } \\
\text { (Btu/kWh) } \\
\text { (LHV) }\end{array}$ \\
\hline 61 & 30.0 & 25.9 & 531 & 0.69 & 312,000 & 395,000 & 13,200 \\
\hline 62 & 30.0 & 25.8 & 533 & 0.69 & 313,000 & 396,000 & 13,200 \\
\hline 63 & 30.0 & 25.8 & 534 & 0.69 & 314,000 & 397,000 & 13,200 \\
\hline 64 & 29.9 & 25.7 & 535 & 0.69 & 314,000 & 397,000 & 13,300 \\
\hline 65 & 29.7 & 25.7 & 536 & 0.69 & 313,000 & 395,000 & 13,300 \\
\hline 66 & 29.5 & 25.6 & 536 & 0.68 & 312,000 & 393,000 & 13,300 \\
\hline 67 & 29.3 & 25.6 & 537 & 0.68 & 311,000 & 392,000 & 13,400 \\
\hline 68 & 29.1 & 25.5 & 537 & 0.68 & 310,000 & 390,000 & 13,400 \\
\hline 69 & 29.0 & 25.4 & 538 & 0.68 & 309,000 & 388,000 & 13,400 \\
\hline 70 & 28.8 & 25.4 & 538 & 0.68 & 308,000 & 387,000 & 13,500 \\
\hline 71 & 28.6 & 25.3 & 539 & 0.68 & 307,000 & 385,000 & 13,500 \\
\hline 72 & 28.4 & 25.3 & 539 & 0.67 & 306,000 & 384,000 & 13,500 \\
\hline 73 & 28.2 & 25.2 & 54() & 0.67 & 305,000 & 382,000 & 13,500 \\
\hline 74 & 28.0 & 25.1 & 54() & 0.67 & 304,000 & 380,000 & 13,600 \\
\hline 75 & 27.8 & 25.1 & 540 & 0.67 & 303,000 & 379,000 & 13,600 \\
\hline 76 & 27.6 & 25.0 & 541 & 0.67 & 302,000 & 377,000 & 13,600 \\
\hline 77 & 27.4 & 24.9 & 541 & 0.66 & 301,000 & 376,000 & 13,700 \\
\hline 78 & 27.3 & 24.9 & 542 & 0.66 & 300,000 & 374,000 & 13,700 \\
\hline 79 & 27.1 & 248 & 542 & 0.66 & 299,000 & 372,000 & 13,700 \\
\hline 80 & 26.9 & 24.8 & 543 & 0.66 & 299,000 & 371,000 & 13,800 \\
\hline 81 & 26.7 & 24.7 & 543 & 0.66 & 298,000 & 369,000 & 13,800 \\
\hline 82 & 26.6 & 24.6 & 544 & 0.66 & 297,000 & 368,000 & 13,800 \\
\hline 83 & 26.4 & 24.6 & 544 & 0.65 & 296,000 & 366,000 & 13,900 \\
\hline 84 & 26.2 & 24.5 & 545 & 0.65 & 295,000 & 365,000 & 13,900 \\
\hline 85 & 26.0 & 24.5 & 545 & 0.65 & 294,000 & 363,000 & 14,000 \\
\hline 86 & 25.8 & 24.4 & 545 & 0.65 & 293,000 & 362,000 & 14,000 \\
\hline 87 & 25.7 & 24.3 & 546 & 0.65 & 292,000 & 360,000 & 14,000 \\
\hline 88 & 25.5 & 24.2 & 546 & 0.65 & 291,000 & 359,000 & 14,100 \\
\hline 89 & 25.3 & 24.2 & 547 & 0.64 & 290,000 & 357,000 & 14,100 \\
\hline 90 & 25.1 & 24.1 & 547 & 0.64 & 289,000 & 355,000 & 14,200 \\
\hline 91 & 24.9 & 24.0 & 548 & 0.64 & 288,000 & 354,000 & 14,200 \\
\hline 92 & 24.7 & 23.9 & 548 & 0.64 & 288,000 & 352,000 & 14,300 \\
\hline 93 & 24.5 & 23.9 & 549 & 0.64 & 287,000 & 351,000 & 14,300 \\
\hline 94 & 24.4 & 23.8 & 549 & 0.64 & 286,000 & 349,000 & 14,300 \\
\hline 95 & 24.2 & 23.7 & 550 & 0.63 & 285,000 & 348,000 & 14,400 \\
\hline 96 & 24.0 & 23.7 & 550 & 0.63 & 284,000 & 346,000 & 14,400 \\
\hline
\end{tabular}


Table 2. Nominal Net Power Output and Efficiency versus Ambient Temperature at Sea Level

\begin{tabular}{|c|c|c|c|c|c|c|c|}
\hline $\begin{array}{c}\text { Ambient } \\
\text { Temp } \\
\left({ }^{\circ} \mathbf{F}\right)\end{array}$ & $\begin{array}{c}\text { Net } \\
\text { Power } \\
(\mathbf{k W})\end{array}$ & $\begin{array}{c}\text { Net } \\
\text { Efficiency } \\
(\%)\end{array}$ & $\begin{array}{c}\text { Exhaust } \\
\text { Temp } \\
\left({ }^{\circ} \mathbf{F}\right)\end{array}$ & $\begin{array}{c}\text { Exhaust Mass } \\
\text { Flow Rate } \\
(\mathrm{lbm} / \mathrm{s})\end{array}$ & $\begin{array}{c}\text { Exhaust } \\
\text { Energy } \\
\text { (Btu/hr) }\end{array}$ & $\begin{array}{c}\text { Fuel Flow } \\
\text { Energy } \\
\text { (LHV) }\end{array}$ & $\begin{array}{c}\text { Heat Rate } \\
\text { (Btu/kWh) } \\
\text { (LHV) }\end{array}$ \\
\hline 97 & 23.8 & 23.6 & 551 & 0.63 & 283,000 & 345,000 & 14,400 \\
\hline 98 & 23.7 & 23.5 & 551 & 0.63 & 282,000 & 343,000 & 14,500 \\
\hline 99 & 23.5 & 23.4 & 551 & 0.63 & 282,000 & 342,000 & 14,500 \\
\hline 100 & 23.3 & 23.4 & 552 & 0.63 & 281,000 & 341,000 & 14,600 \\
\hline 101 & 23.1 & 23.3 & 552 & 0.62 & 280,000 & 339,000 & 14,700 \\
\hline 102 & 23.0 & 23.2 & 553 & 0.62 & 279,000 & 338,000 & 14,700 \\
\hline 103 & 22.8 & 23.1 & 553 & 0.62 & 278,000 & 336,000 & 14,700 \\
\hline 104 & 22.6 & 23.1 & 554 & 0.62 & 277,000 & 335,000 & 14,800 \\
\hline 105 & 22.5 & 23.0 & 554 & 0.62 & 276,000 & 333,000 & 14,800 \\
\hline 106 & 22.3 & 22.9 & 555 & 0.62 & 275,000 & 332,000 & 14,900 \\
\hline 107 & 22.1 & 22.9 & 555 & 0.61 & 275,000 & 331,000 & 14,900 \\
\hline 108 & 22.0 & 22.8 & 555 & 0.61 & 274,000 & 329,000 & 15,000 \\
\hline 109 & 21.8 & 22.7 & 556 & 0.61 & 273,000 & 328,000 & 15,000 \\
\hline 110 & 21.6 & 22.6 & 556 & 0.61 & 272,000 & 326,000 & 15,100 \\
\hline 111 & 21.5 & 22.5 & 557 & 0.61 & 271,000 & 325,000 & 15,100 \\
\hline 112 & 21.3 & 22.5 & 557 & 0.60 & 270,000 & 324,000 & 15,200 \\
\hline 113 & 21.1 & 22.4 & 558 & 0.60 & 270,000 & 322,000 & 15,200 \\
\hline 114 & 21.0 & 22.3 & 558 & 0.60 & 269,000 & 321,000 & 15,300 \\
\hline 115 & 20.8 & 22.2 & 558 & 0.60 & 268,000 & 319,000 & 15,400 \\
\hline 116 & 20.6 & 22.1 & 559 & 0.60 & 267,000 & 318,000 & 15,400 \\
\hline 117 & 20.5 & 22.1 & 559 & 0.60 & 266,000 & 317,000 & 15,500 \\
\hline 118 & 20.3 & 22.0 & 560 & 0.59 & 265,000 & 314,000 & 15,500 \\
\hline 119 & 20.1 & 21.9 & 560 & 0.59 & 265,000 & 322,000 & 15,600 \\
\hline 120 & 20.0 & 21.8 & 561 & 0.59 & 264,000 & 313,000 & 15,600 \\
\hline 121 & 19.8 & 217 & 561 & 0.59 & 263,000 & 311,000 & 15,700 \\
\hline 122 & 19.7 & 21.7 & 561 & 0.59 & 262,000 & 310,000 & 15,800 \\
\hline
\end{tabular}




\section{Elevation Derating}

Elevation affects power output by changing the density of the air. Although local weather changes in barometric pressure have the same effect, power derating for elevation may be estimated to be $1.0 \%$ per 100 meters above sea level (3.0\% per 1000 feet above sea level), assuming equivalent ambient temperatures.

Use these derating estimates only for ambient temperatures above $15^{\circ} \mathrm{C}\left(59^{\circ} \mathrm{F}\right)$, as lower ambient temperatures may offset the effects of elevation. Elevation effect on efficiency is negligible.

\section{Back Pressure Derating}

The maximum allowable exhaust back pressure is eight inches of water. Nominal fraction of ISO net power output and efficiency versus back pressure at ISO ambient conditions for the Model C30 MicroTurbine operating on natural gas (B Range) fuel is presented in Table 3. These values are estimated from nominal performance curves.

Table 3. Nominal Fraction of ISO Net Power Output and Efficiency versus Back Pressure at ISO Ambient Conditions

\begin{tabular}{|c|c|c|c|c|}
\hline $\begin{array}{c}\text { Back Pressure } \\
\text { (inches of water) }\end{array}$ & $\begin{array}{c}\text { Net Power } \\
(\mathbf{k W})\end{array}$ & $\begin{array}{c}\text { Net Efficiency } \\
\mathbf{( \% )}\end{array}$ & $\begin{array}{c}\text { Power } \\
\text { (power @ Pback= } \mathbf{~})\end{array}$ & $\begin{array}{c}\text { Efficiency } \\
\text { (efficiency @ Pback= } \mathbf{~} \text { ) }\end{array}$ \\
\hline 0 & 30.00 & 26.0 & 1.000 & 1.000 \\
\hline 1 & 30.00 & 25.9 & 1.000 & 0.997 \\
\hline 2 & 30.00 & 25.8 & 1.000 & 0.994 \\
\hline 3 & 30.00 & 25.8 & 1.000 & 0.991 \\
\hline 4 & 30.00 & 25.7 & 1.000 & 0.989 \\
\hline 5 & 30.00 & 25.6 & 1.000 & 0.986 \\
\hline 6 & 30.00 & 25.5 & 1.000 & 0.982 \\
\hline 7 & 29.98 & 25.5 & 0.999 & 0.979 \\
\hline 8 & 29.84 & 25.4 & 0.995 & 0.976 \\
\hline
\end{tabular}

410004-001 Rev A (August 2002) 


\section{Appendix D}

\section{Additional Photographs of Demonstration Setup}




\section{Appendix D \\ Additional Photographs of Demonstration Setup}

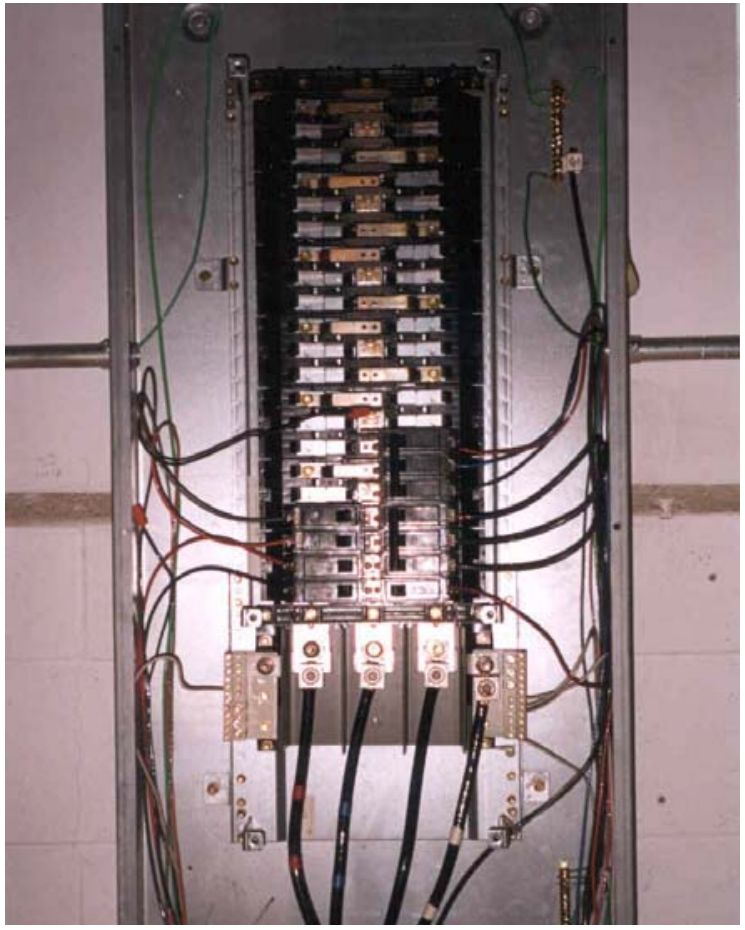

Figure D.1. Panel that serves the mechanical room pumps, fans, and power burners 


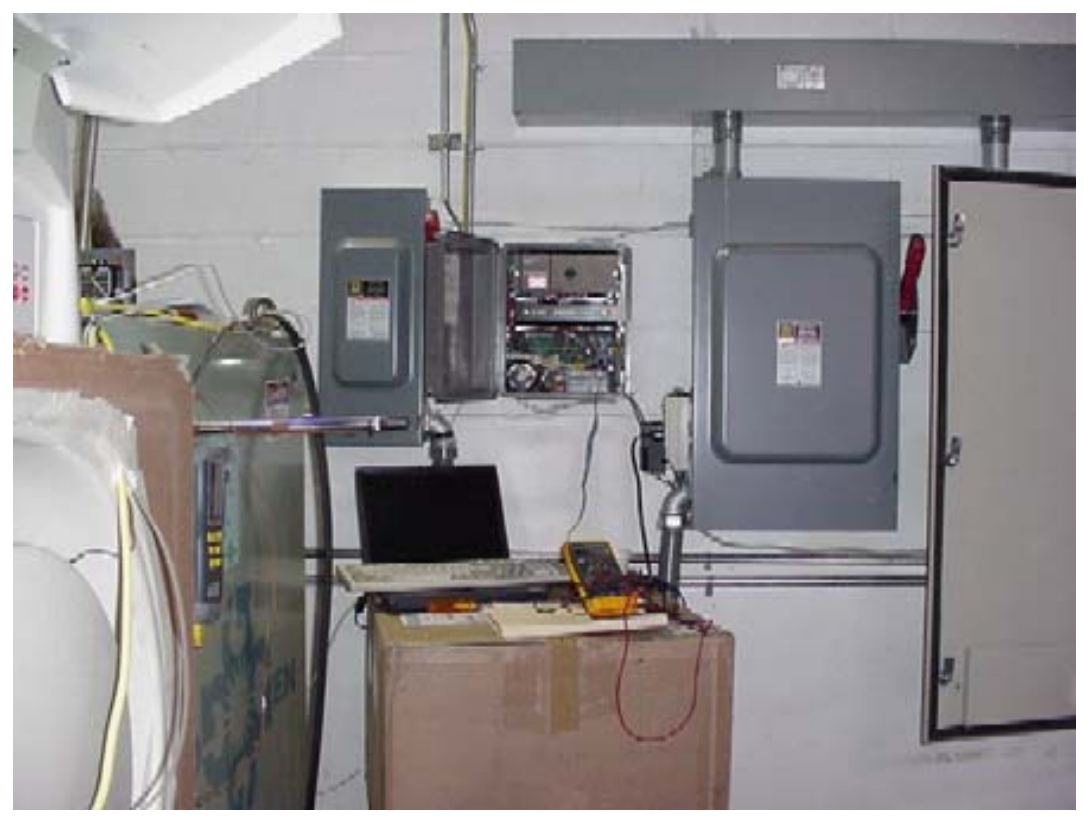

Figure D.2. Step-down transformer (bottom) with disconnects on 480V (left) side and 208V (right) side. MT and RHX are at far left. Data acquisition system is mounted on the wall between disconnects.

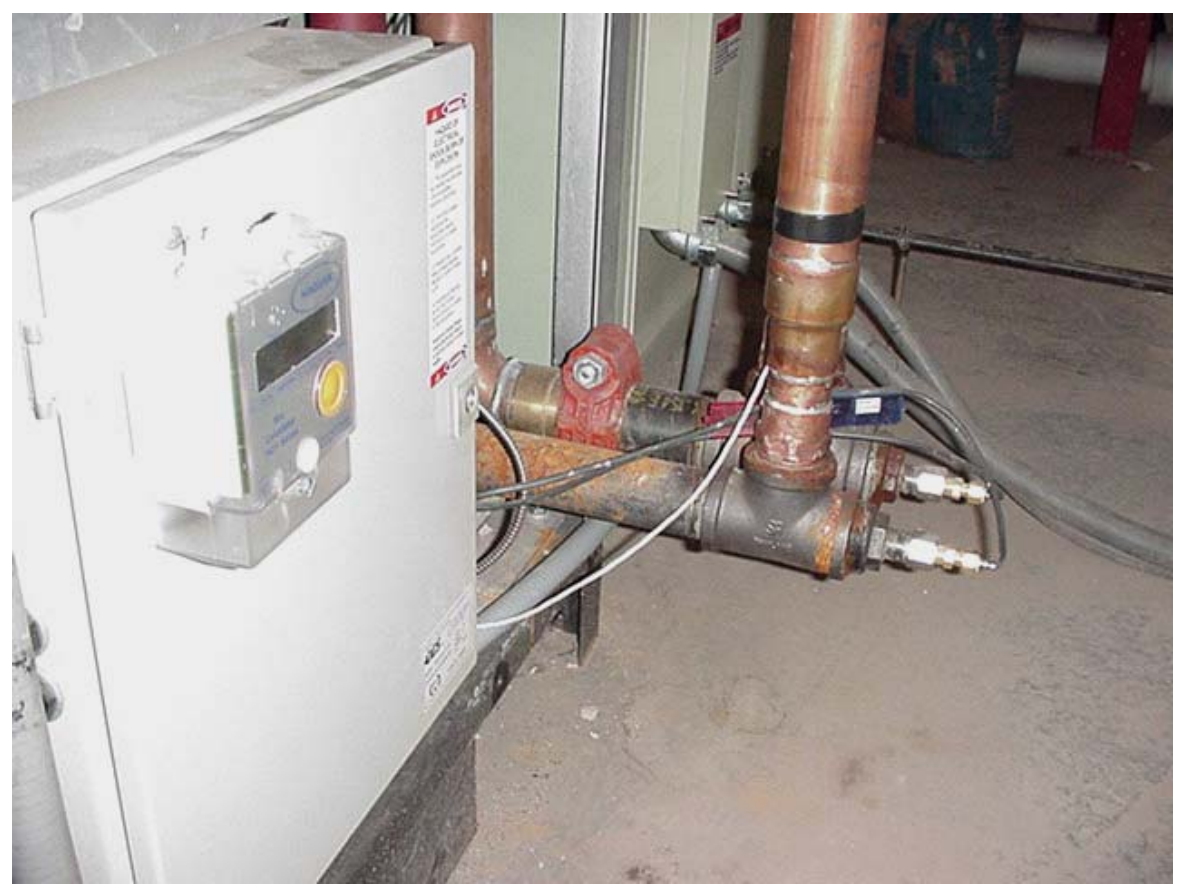

Figure D.3. Btu meter mounted on back access door of RHX (left) and RHX water-side thermowells mounted in the inlet and outlet T fittings (center). 


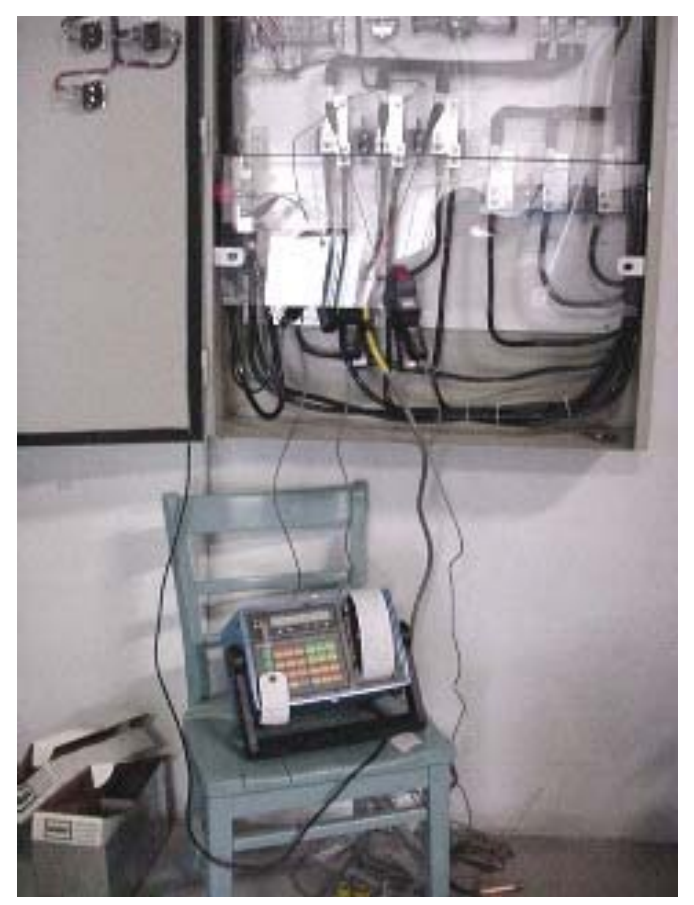

Figure D.4. Control panel (top) with Dranetz power analyzer hooked up

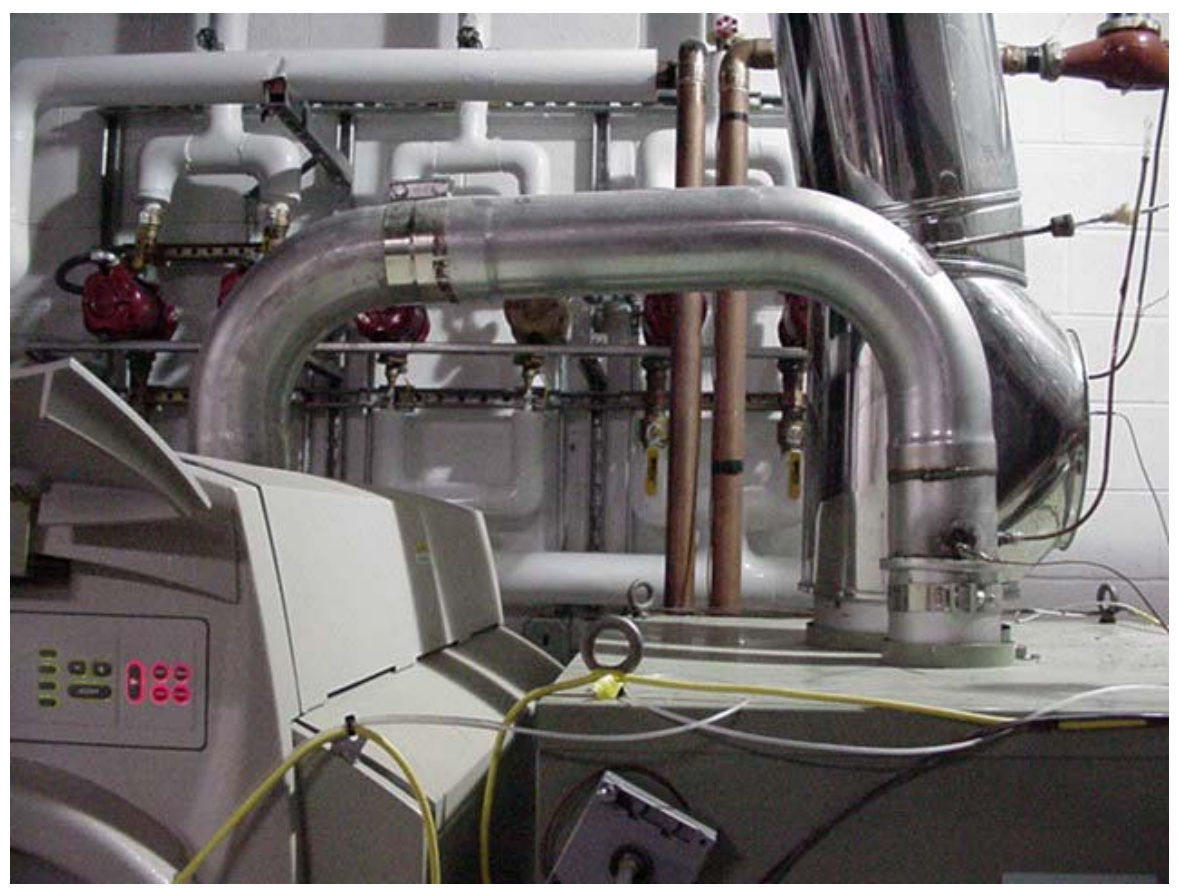

Figure D.5. Exhaust duct from MT to RHX. Larger RHX exhaust stack to roof is partially hidden. Water meter that measures RHX flow rate is just visible in upper right. 


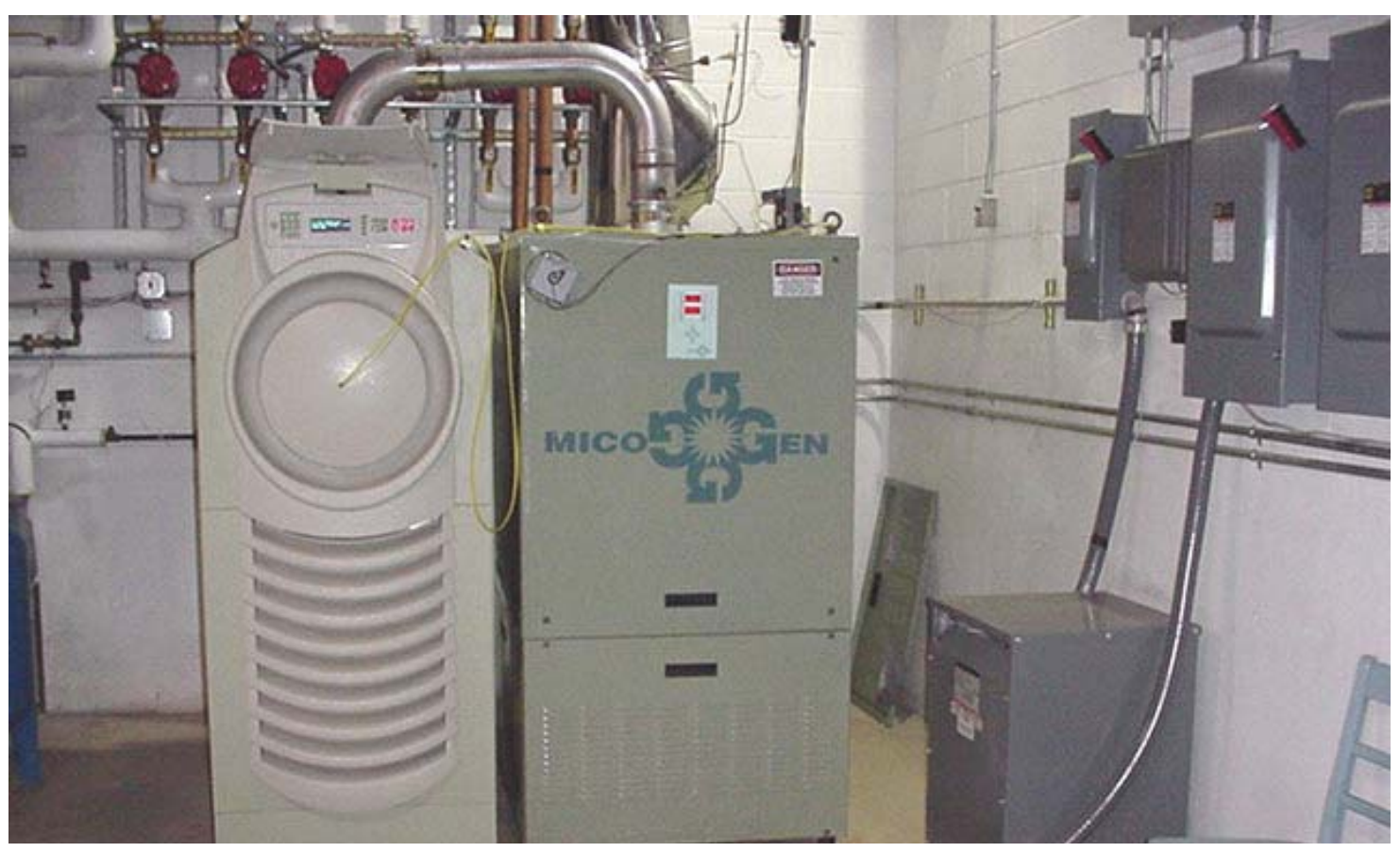

Figure D.6. Overview (L to R) of MT, RHX, transformer, and switchgear. Note DHW recirculation pumps on wall above and behind the microturbine. 


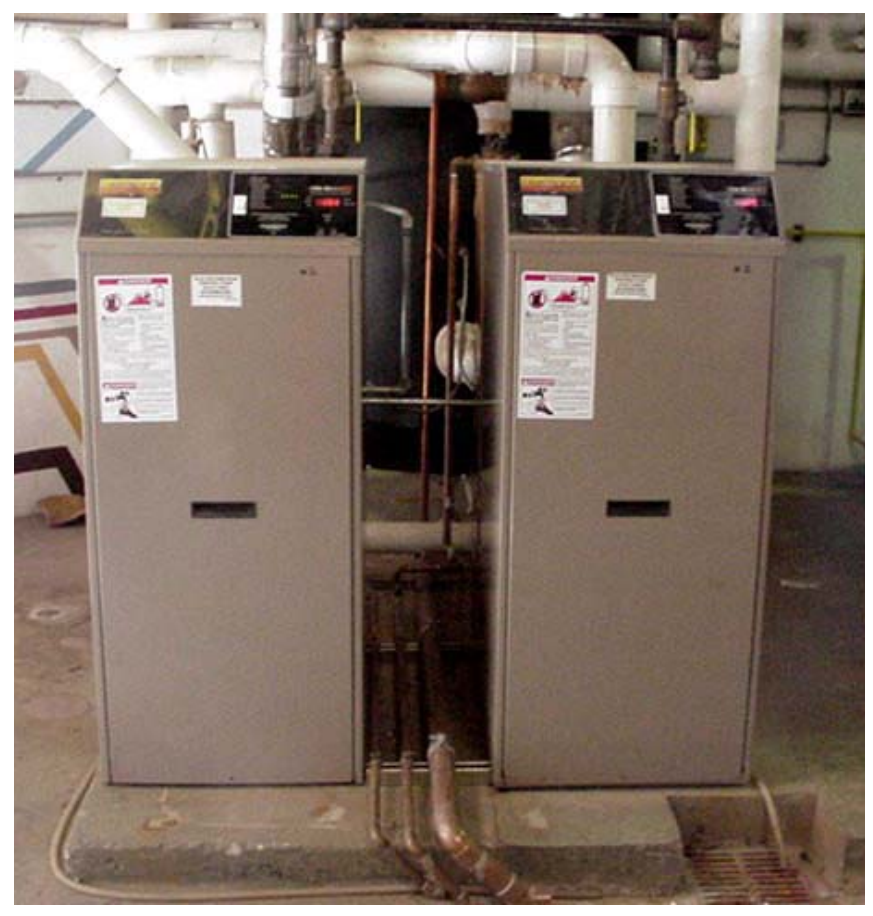

Figure D.7. HW heaters

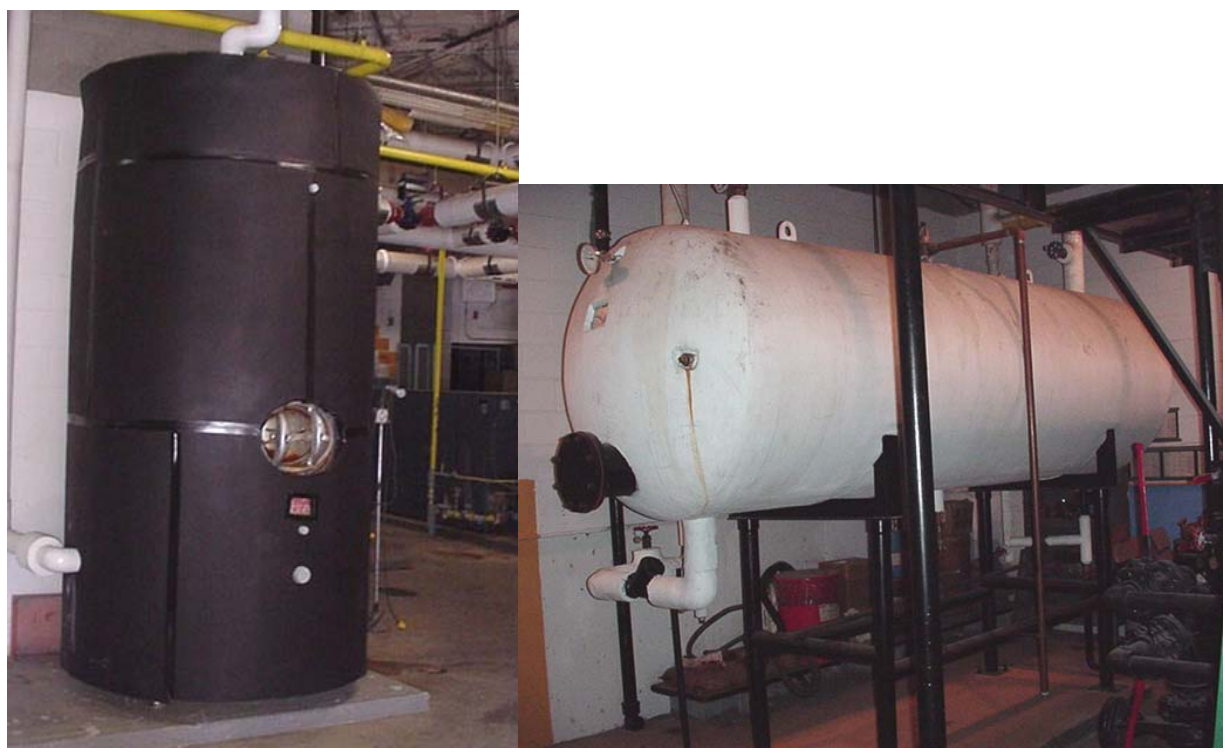

Figure D.8. New (left) and Existing (right) hot water storage tanks 


\section{Appendix E}

Sources and Points of Contact 


\section{Appendix E \\ Sources and Points of Contact}

\section{Microturbine OEM}

Capstone Turbine Corporation

21211 Nordhoff Street

Chatsworth, CA 91311

Phone: (818) 734-5300

www.microturbine.com

\section{micoGen $^{\text {TM }}$ Heat Exchanger OEM}

UNIFIN International, Inc.

1030 Clarke Side Road

London, Ontario, Canada N6A 4P4

Phone: (800) 567-5707

www.unifin.com

Microturbine and micoGen ${ }^{\mathrm{TM}}$ Heat Exchanger Distributorship

Enertec, LLC

55A East Ridgewood Ave., Suite 8

Ridgewood, NJ 07450

POC: James R. Pfeiffer, V.P. (201) 251-3815

Email: pfeifferjr@aol.com

www.enertecllc.com

\section{Contractor}

JW's Mechanical, LLC

21 Liberty Street

Carthage, NY 13619

POC: John Ashcroft (315) 493-7642

Email: Ashcroft@northnet.org

\section{Contributors}

Department of the Army

Headquarters United States Army Forces Command

1777 Hardee Avenue SW

Fort McPherson, GA 30330-1062

POC: Steve Jackson 
U.S. Department of Energy

Federal Energy Management Program

New Technology Demonstration Program

1000 Independence Ave. SW

Washington, D.C. 20585

POC: Ted Collins (202) 586-8017

Email: theodore.collins@ee.doe.gov

Vicksburg Consolidated Contracting

Champaign Office

PO Box 9005

Champaign IL 61826-9005

Contract/Purchase Order \#DACW42-02-P-0021

U.S. Army Corps of Engineers - Engineering Research Development Center

Construction Engineering Research Laboratory

2902 Newmark Drive

Champaign, IL 61822-1076

Technical POC: William R. Taylor (217-352-6511 ext. 6393)

Alternate Technical POC: Roch Ducey (800-USA-CERL ext. 7444)

U.S. Army—Fort Drum

Department of Public Works

85 First Street West

Watertown, NY 13602-5097

POC: Steve Rowley (315) 772-5433

Email: rowleys@drum.army.mil

Pacific Northwest National Laboratory

PO Box 999, MS k5-16

Richland, WA 99352-0999

POC: Michele Friedrich (509) 375-5989

Email: mfriedrich@pnl.gov

or David L Smith (509) 372-4553 


\section{Distribution}

No. of

Copies

\section{OFFSITE}

William Carroll

Lawrence Berkeley National Laboratory

1 Cyclotron Road, B-90 MS: 1023

Berkeley, CA 94720

Julia Kelley

Oak Ridge National Laboratory

1 Bethel Valley Road

P.O. Box 2008, Building 3147

Oak Ridge, TN 37831-6070

Sheila Hayter

National Renewable Energy Laboratory

1670 Cole Blvd.

Golden, CO 80401

6 U.S. Department of Energy-FEMP

ATTN:T. Collins (4)

S. Herrera

S. Schell

1000 Independence Avenue, SW

Washington D.C. 20585

Lisa Hollingsworth

U.S. Department of Energy

Atlanta Regional Office

730 Peachtree Street, NE, Suite 76

Atlanta, GA 30308

Randy Jones

U.S. Department of Energy

Denver Regional Office

1617 Cole Boulevard

Golden, CO 80401
No. of

Copies

Paul King

U.S. Department of Energy

Boston Regional Office

JFK Federal Building, Room 675

Boston, MA 02203

C. Marchione

U.S. Department of Energy

Philadelphia Regional Office

1880 JFK Boulevard, Suite 501

Philadelphia, PA 19102

Arun Jhaveri

U.S. Department of Energy

Seattle Regional Office

800 Fifth Avenue, Suite 3950

Seattle, WA 98104

Melinda Latimer

U.S. Department of Energy

Chicago Regional Office

1 South Wacker Drive, Suite 2380

Chicago, IL 60606

4 Steve Rowley

U.S. Army Fort Drum

Department of Public Works

85 First Street West

Watertown, NY 13602-5097

William R. Taylor

U.S. Army Corps of Engineers - C E R L

2902 Newmark Drive

Champaign, IL 61822-1076 